Article

\title{
Textural Identification of Polycrystalline Magmatic, Tectonically-Deformed, and Shock-Related Zircon Aggregates
}

\author{
Elizaveta Kovaleva
}

Department of Geology, University of the Free State, 205 Nelson Mandela Drive, Bloemfontein 9300, Free State, South Africa; kovalevae@ufs.ac.za; Tel.: +27-15-401-9257

Received: 7 April 2020; Accepted: 19 May 2020; Published: 21 May 2020

\begin{abstract}
Zircon with polycrystalline or polygranular appearance is either produced in the magmatic environment through crystallization, or due to deformation in metamorphic settings (including regional metamorphism and ductile shear zones), or as a result of shock-induced recrystallization. All three types can be easily confused and potentially lead to incorrect interpretations, especially if the crystallographic orientation analyses of zircon are not conducted. It is particularly important to establish the difference between tectonically-deformed polygranular zircon and shock-induced polygranular zircon because the latter serves as an indicator of shock event and is often used for dating asteroid impacts. In this paper, a series of polycrystalline zircon grains from ductile shear zones and metamorphic rocks are analyzed using a combination of techniques (BSE, CL, orientation contrast, EBSD, and microprobe mapping), and their properties are compared to reported polycrystalline zircons from magmatic and impact settings. This work shows how appearance, crystallographic orientation, and CL signature of "granules" differ between the different types of deformed zircon.
\end{abstract}

Keywords: EBSD; shear zones; Eastern Alps; Southern Alps; impact recrystallization; granitoids

\section{Introduction}

Zircon is an important accessory mineral, widely used for isotopic dating in geochronology [1-4]. Usually, the zircon phase grows in magmatic and metamorphic rocks as regular single crystals with euhedral and subhedral shapes, elongation ratio from 1 to 5, and from 30 to $250 \mu \mathrm{m}$ in size [5,6]. Rarely, in felsic igneous rocks such as anatectic granites, zircon demonstrates twinning and aggregates of 2-20 interconnected grains [7-11]. In metamorphic rocks, detrital zircon can be fragmented or corroded and then healed and overgrown by a new metamorphic rim, resulting in "cauliflower" or complicated polygranular or polycrystalline shapes [12-14].

It was first discovered in the early 1990s that under shock conditions, zircon develops polygranular textures (also called "granular" or "polycrystalline" in the literature) with fine granules from 0.5 to $3 \mu \mathrm{m}$ in diameter [15-19], but attempts to date an impact event with this polygranular zircon were not entirely successful $[20,21]$. In the last decade, zircon was intensely studied for shock-induced deformation, and various polycrystalline types were distinguished using an electron backscatter diffraction (EBSD) mapping [22-28]. For example, polygranular neoblastic zircon with systematically-oriented fine granules is believed to be formed after reidite and can be dated for the age of an impact event $[28,29]$. The fine granules in such zircon have metamict cores, well-crystalline rims, and are (sub)rounded in shape [30]. At the same time, the parent grain might retain its initial zonation [30].

Zircon re-crystallized to larger unsystematically-oriented granules also yields isotopic ages of impact events $[22,23,27]$. Such granules have euhedral shapes, concentric CL-zoning and can be from 5 up to $100 \mu \mathrm{m}$ long, being located within the boundaries of pre-existing grain [22,27]. Other described 
types of polygranular zircon include fine granules with random orientations and granules with no misorientation with respect to each other [28,30]. Polygranular zircon was also found in lunar samples [31-34] and meteorites [35], but the nature of its re-crystallization is not well understood. Likely, there are more types of shock-induced polycrystalline textures in zircon to be discovered.

Occasionally, polygranular zircons derived from impactites appear to be shock-recrystallized, judging from their exterior but do not yield the isotopic age of an impact event, or show discordant ages $[23,28]$. The polycrystalline appearance of such grains might not be related to the impact event, but could be a result of pre-impact metamorphic deformation and re-working [36]. This study demonstrates the types and properties of deformed zircon from Alpine shear zones and metamorphic rocks that have a polycrystalline appearance and compares them to reported shock-recrystallized and magmatic grains. The motivation is to understand the nature of the differences and prevent confusion of polycrystalline genetic types in the future. This work will improve interpretations of polygranular zircons from terrestrial and lunar impactites and has implications for geochronology.

\section{Geological Settings and Samples}

The samples were collected from localities within the Southern Alps (Italy) and Eastern Alps (Austria).

\subsection{The Ivrea-Verbano Zone, Val d'Ossola, Northern Italy, Southern Alps}

The Ivrea-Verbano Zone (IVZ) in the Southern Alps is a tectonic unit that has a lens shape and stretches from southwest to northeast. The IVZ consists of meta-sedimentary and meta-igneous mafic rocks, ultrabasic mantle tectonites, and a mantle igneous complex. The sequence is overturned so that the metasedimentary rocks are exposed in the SE, whereas metabasic rocks and depleted metapelites are exposed in the NW. Metamorphism gradually increases from amphibolite facies in the SE to granulite facies in the NW. The IVZ is a section of the lower continental crust that was metamorphosed during the uppermost Palaeozoic, and then tectonically uplifted and rotated sideways to its present position. The Insubric shear zone limits IVZ at the NW, and the Pogallo line limits it at the SE [37-39]. The IVZ is crosscut by a network of shear zones stretching along the general NE-SW elongation direction [37], which accommodate a post-Hercynian lower crustal extension [40]. Shear zones were formed in simple shear conditions, as supported by structural observations [37,41,42].

The sample (IV12-07A) was collected at the village Premosello in Val d'Ossola, from one such shear zone $\left(46^{\circ} 00^{\prime} 15.04^{\prime \prime} \mathrm{N}, 08^{\circ} 19^{\prime} 44.11^{\prime \prime} \mathrm{E}\right)$. The sample is a strongly restitic, highly dehydrated metasedimentary felsic ultramylonite with thin pseudotachylite veins [43]. This lithology was described in more detail by [44] and [45,46]. The mylonitic metapelite is metamorphosed under amphibolite-facies conditions with the peak P-T estimates of 550-650 ${ }^{\circ} \mathrm{C}$ and 0.4-0.6 GPa [44]. Pseudotachylytes in the sample are overprinted by ultramylonites and are interpreted to have formed coevally [44]. The sample contains garnet clasts ranging from 50 to $500 \mu \mathrm{m}$ in size, surrounded by a fine-grained foliated matrix consisting of alternating plagioclase-, quartz-, and biotite-ilmenite rich layers. Zircon and monazite are common accessory minerals [46].

In the studied thin section, 38 zircon grains were observed, mostly enclosed in the mylonitic matrix, with only four grains hosted by garnet porphyroclasts. Zircons are subrounded, with the aspect ratio from 1:1 to 1:2, from 8 to $60 \mu \mathrm{m}$ in length, with the average size of $30 \mu \mathrm{m}$. Most of them have CL-dark detrital cores with concentric or mosaic zonation, overgrown by wide CL-bright metamorphic rim. A few grains have diffuse CL-bright signature. From 38 grains, three have a polycrystalline appearance (ca. 8\%), 12 exhibit moderate fractures (including two of the three polycrystalline grains, ca. $32 \%), 4$ have a very low degree of internal lattice deformation (ca. $10 \%$ ).

\subsection{The Western Tauern Window, Tyrol, Southern Austria, Eastern Alps}

The Western Tauern Window (WTW) within the Eastern Alps exposes the footwall of the Austro-alpine nappe stack, in particular, the continental and oceanic rocks of the Penninic and 
sub-Penninic nappe sequence. Nappe stacking and amphibolite-facies peak metamorphism in the sampling area are related to the closure of the Neotethys and continental collision in the Tertiary [47]. Samples were collected from the 'Zillertaler Kern' lobe of the 'Zentralgneis' formation [46,48]. The age of the granitic protolith of the 'Zentralgneis' formation is uppermost Devonian to lower Permian [49]. These granitoids intruded into pre-Carboniferous polymetamorphic basement composed of schists, meta-sedimentary, and meta-igneous rocks, amphibolites, and meta-ophiolites. The 'Zentralgneis' formation in the Zillertal section was metamorphosed under the amphibolite-facies regional conditions of 550-600 ${ }^{\circ} \mathrm{C}$ and 0.5-0.7 GPa at ca. $30 \mathrm{Ma}$ [48], accompanied by ductile deformation localized along fractures and other planar heterogeneities [50]. After metamorphism, the unit experienced rapid exhumation at ca. $20 \mathrm{Ma}$ [51].

In the studied area, deformed and foliated granodioritic gneisses are observed, with abundant sigma-clasts, bookshelf structures, deformed and offset dykes and veins, and ductile shear zones. The ca. $50 \mathrm{~m}$-thick ductile fluid-aided shear zone is exposed on the NE slope of the small valley that joins the main Zemmbach valley from the southeast $\left(47^{\circ} 01^{\prime} 39.308^{\prime \prime} \mathrm{N}, 11^{\circ} 50^{\prime} 3.669^{\prime \prime} \mathrm{E}\right)$. The shear zone represents a zone of alternating ultramylonitic and mylonitic portions of the quartz-biotite orthogneiss (samples BH12-01 and BH12-02 accordingly; BH12-02 contains sigma-clasts), which are hosted by weakly- to strongly-foliated gneiss of granitic composition (samples BH12-04 and BH12-06 accordingly), enriched in biotite and muscovite and crosscut by leucocratic veins (see also [14], "shear zone 1").

Sample BH12-01 comprises ultramylonite in sharp contact with foliated granitic gneisses. The ultramylonitic layer is composed of a fine-grained, recrystallized plagioclase-quartz matrix (grain size: $70-300 \mu \mathrm{m}$ in diameter, $>95$ vol.\%), with minor amounts of biotite, white mica and epidote $(<5 \%$ in total), which form a weak foliation. Along plagioclase boundaries, a few $\mu \mathrm{m}$-thin K-feldspar-veins occur. Zircon, apatite, and titanite are common accessory minerals. Zircon forms small (5-10 $\mu \mathrm{m}$ in diameter) rectangular grains, with aspect ratios from 1:1 to 1:3.

The foliated granite gneiss in contact with ultramylonite in the sample BH12-01, as well as samples BH12-02, BH12-04, and BH12-06, exhibit varying degrees of metamorphic recrystallization. Sample BH12-02 exhibits lower recrystallization than the BH12-01 and contains sigmoidal clasts of plagioclase and quartz enclosed in the mylonitic matrix. Samples BH12-04 and BH12-06, collected from the host rock of shear zone, are weakly recrystallized, non-foliated, or weakly-foliated granitic orthogneiss. The granite gneisses are composed of plagioclase, quartz, biotite, and white mica, as well as K-feldspar veinlets. Biotite is locally replaced by an association of titanite, chlorite, quartz, and epidote. The even or sigmoidal foliation is represented by leucocratic layers of plagioclase-quartz and layers consisting of plagioclase, quartz, biotite, white mica, and epidote. In some domains, the foliation is defined by pure mica bands. Zircons in this sample sequence have 2 to $50 \mu \mathrm{m}$ grain size, euhedral to subhedral shapes, and aspect ratio from 1:1 to 1:2. In samples BH12-04 and BH12-06, the zircon aspect ratio reaches 1:5. Zircons are hosted by plagioclase or biotite grains, sometimes associated with epidote and apatite. The smaller non-deformed grains show oscillatory and sector zoning, which is truncated by recrystallization zones or marginal overgrowths, both of which appear bright in CL-images. More than half (57\%) of the investigated zircon grains from a sample suite appear to be plastically and/or brittlely deformed. Sample BH12-02 contains ca. $46 \%$ of deformed zircon grains. Samples BH12-04 and BH12-06 contain ca. 16\% plastically and/or cataclastically deformed zircon grains [14].

In the sample BH12-01, in its ultramylonitic part, 17 zircon grains were observed. Of those, one has a polycrystalline appearance of metamorphic origin (see explanation below, ca. $6 \%$ ), and three have open or healed fractures (ca. 18\%). In the foliated mylonitic part of the sample BH12-01, 91 zircon grains were observed from two thin sections. Of those, 18 have the polycrystalline appearance of metamorphic origin (ca. 20\%), and 15 reveal moderate fracturing, open or healed (ca. 16\%). In the sample BH12-02, 60 zircon grains were examined in one thin section, of those 8 have a polygranular appearance of metamorphic origin (13\%) and 16 exhibit fractures, open and, more frequently, healed $(27 \%)$. In the sample BH12-04, 53 zircon grains were observed in one thin section, of which four 
have a polygranular appearance of magmatic origin (see explanation below, ca. 7\%), nine have the polygranular appearance of metamorphic origin (17\%) and six exhibit opened or healed fractures (11\%). In the sample BH12-06, in two thin sections, 103 zircon grains were observed. Of those, 26 possess the polygranular appearance of metamorphic origin (25\%), and 22 have open or healed fractures (21\%).

\section{Methodology}

\subsection{Sample Preparation}

Zircon grains were examined in polished thin sections, mechanically prepared with $0.25 \mu \mathrm{m}$ diamond paste, and chemically polished with alkaline colloidal silica solution (Köstrosol 3530; $\mathrm{pH}$ 9.2-10) on a rotary-head polishing machine for $4 \mathrm{~h}$.

\subsection{Scanning Electron Microscopy (SEM) and Cathodoluminescence (CL) Imaging}

All zircon grains were identified and characterized by secondary electron (SE), backscattered-electron (BSE), and cathodoluminescence (CL) images, using an FEI Inspect S scanning electron microscope equipped with a MonoCL system (Gatan) at the Faculty of Earth Sciences, Geography and Astronomy, University of Vienna (Vienna, Austria). Imaging conditions were at $10 \mathrm{kV}$ accelerating voltage, with a CL-image resolution of $1500 \times 1500$ to $2500 \times 2500$ pixels using a dwell time of $80.0-150.0 \mathrm{~ms}$ and probe current/spot size $4.5-5.0$.

\subsection{Electron Backscatter Diffraction (EBSD) Analysis}

Zircon grains were examined for potential crystal-plastic deformation microstructures using orientation contrast images taken by a forescatter electron detector (FSD) mounted on the EBSD-tube of an 3D FEG instrument (FEI Quanta) equipped with a Schottky field emission electron source, at the Faculty of Earth Sciences, Geography and Astronomy, University of Vienna (Vienna, Austria). Electron beam conditions were $15 \mathrm{kV}$ accelerating voltage, 2.5-4 nA probe current using the analytic mode. Stage settings were at $70^{\circ}$ tilt and $14-16 \mathrm{~mm}$ working distance. After identification of potentially deformed crystals, EBSD orientation mapping was applied to selected zircon crystals using the same instrument, which is equipped with an EDAX Pegasus Apex 4 system consisting of a Digiview IV EBSD camera and an Apollo XV silicon drift detector for EDX analysis. EDX intensities and EBSD data were collected simultaneously using OIM v6.21 data collection software (Supplementary Materials). Texture component EBSD maps and pole figures were produced using the EDAX OIM v6.21 Analysis software. Local misorientation EBSD maps were produced by the MatLab MTEX 3.5.0 toolbox. For detailed EBSD methodology and data representation, see $[45,46]$.

\subsection{Microprobe Mapping}

Wavelength dispersive X-ray element distribution maps were obtained with a JXA-8500F Hyperprobe electron probe microanalyzer (EPMA, JEOL), equipped with a thermal field emission gun (Schottky emitter) at the Helmholtz Centre Potsdam, GFZ, Germany. The following trace elements were mapped: $\mathrm{Al}, \mathrm{K}, \mathrm{Pb}, \mathrm{Si}, \mathrm{U}, \mathrm{Y}, \mathrm{Yb}$, and $\mathrm{Zr}$. For more analytical and calibration details, see [52].

\section{Results}

\subsection{Sample IV12-07A, Felsic Mylonitic Metapelite, Ivrea Zone}

Grain 32 has a crescent shape and is composed of several large subgrains, up to $30 \mu \mathrm{m}$ across. Cumulative misorientation within the grain does not exceed $3^{\circ}$, and misorientation between individual subgrains varies between 1.5 and $3^{\circ}$. The misorientation of the fragments is not systematic (see [46], their Figure 8C). In CL, grain 32 has a dark core with complicated faint zonation and polycrystalline lobate appearance, and a bright irregular concentric rim 5-20 $\mu \mathrm{m}$ thick. Subgrain boundaries are visible in CL image, crosscutting the dark core as bright linear features with bright areolae (Figure 1D). 
These CL-bright low-angle boundaries create a polygranular and lobate appearance of the CL-dark core. The low-angle boundaries between subgrains are sharp in EBSD maps (Figure 1B,C), but are diffuse in the CL image, revealing areolae of CL-lighter material extending into CL-dark core. These areolae could be as wide as $10 \mu \mathrm{m}$. Central low-angle boundary in the upper part accommodates the least misorientation and has no CL-bright areola. Thus, alteration is less along the subgrain boundaries with smaller misorientation and more along the subgrain boundaries with larger misorientation.

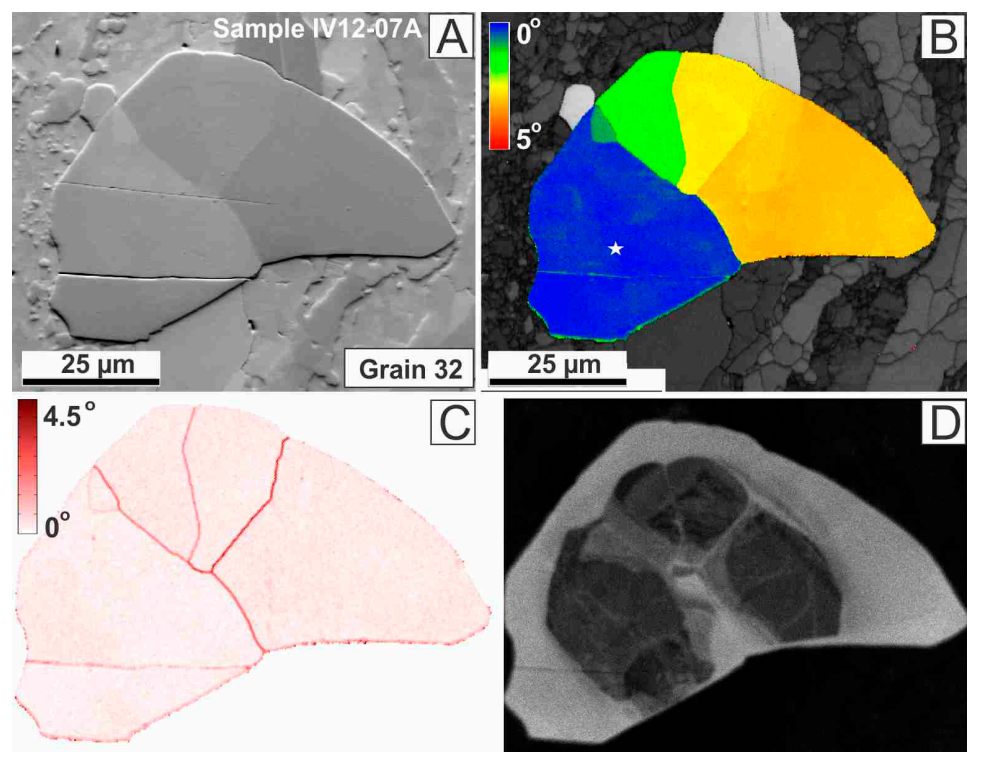

Figure 1. Maps of the zircon grain 32, sample IV12-07A. (A) Orientation contrast image showing several subgrains. (B) Cumulative misorientation EBSD map or texture component map, the orientation of each pixel is shown relative to the orientation of the user-selected reference point (white star). Misorientation varies from 0 (blue) to ca. $3^{\circ}$ (orange). (C) Local misorientation EBSD map, showing misorientation of every pixel with respect to its neighbors. Local misorientation does not exceed $4^{\circ}$. The map shows low-angle boundaries that separate strain-free subgrains. (D) CL image showing a dark core and bright metamorphic rim.

Grain 33 has an irregular quartz inclusion in the middle and consists of multiple subgrains from 5 to $50 \mu \mathrm{m}$ in size, with the maximum relative internal misorientation of ca. $9^{\circ}$ (Figure $2 \mathrm{~A}$ ). The misorientation of the fragments is not systematic (see [46], their Figure 8D). Several subhorizontal fractures crosscut the grain (Figure 2C, black lines), but only two accommodate significant misorientation (Figure 2A, black dashed lines). Most of the misorientation is accommodated by the low-angle boundary network (Figure 2A, white, red, and black solid lines, see figure caption for color-coding). CL imaging reveals dark irregularly-shaped and concentrically-zoned core and a bright rim. The CL-dark core contains bright and, less frequently, dark features that spatially correspond to low-angle boundaries in the EBSD map (Figure 2B, arrows). The BSE image reveals a bright core and darker rim; few BSE-dark features spatially correspond to low-angle boundaries (Figure 2C), but most of the low-angle boundaries coincide with the sharp transitions in BSE intensity, which represents orientation contrast.

Chemical maps reveal a Y-, U- and Yb-enriched irregularly-shaped core and depleted irregular rim. REE- and U-depletion in the CL-bright rim indicates its formation as metamorphic overgrowth or by interface dissolution-reprecipitation $[53,54]$. Trace element-enriched core is crosscut by linear features of depletion corresponding to sub-horizontal fractures that produce misorientation (thick dotted lines in Figure 2A,D) and to low-angle boundaries (Figure 2D, solid lines).

Depleted zones mostly correspond to those low-angle boundaries, which misorientation exceeds $2^{\circ}$ (red and black solid lines in Figure 2). These depleted linear zones, however, are thicker than corresponding low-angle boundaries and do not exactly coincide spatially; the lack of exact coincidence 
could be related to re-polishing of the samples before microprobe mapping. The chemical mapping of $\mathrm{Al}$ and $\mathrm{K}$ did not yield any data within the zircon grain and are not included in this paper. Si and $\mathrm{Zr}$ are depleted along the open fractures, and $\mathrm{Pb}$ appears to be homogeneously distributed (Figure 3).

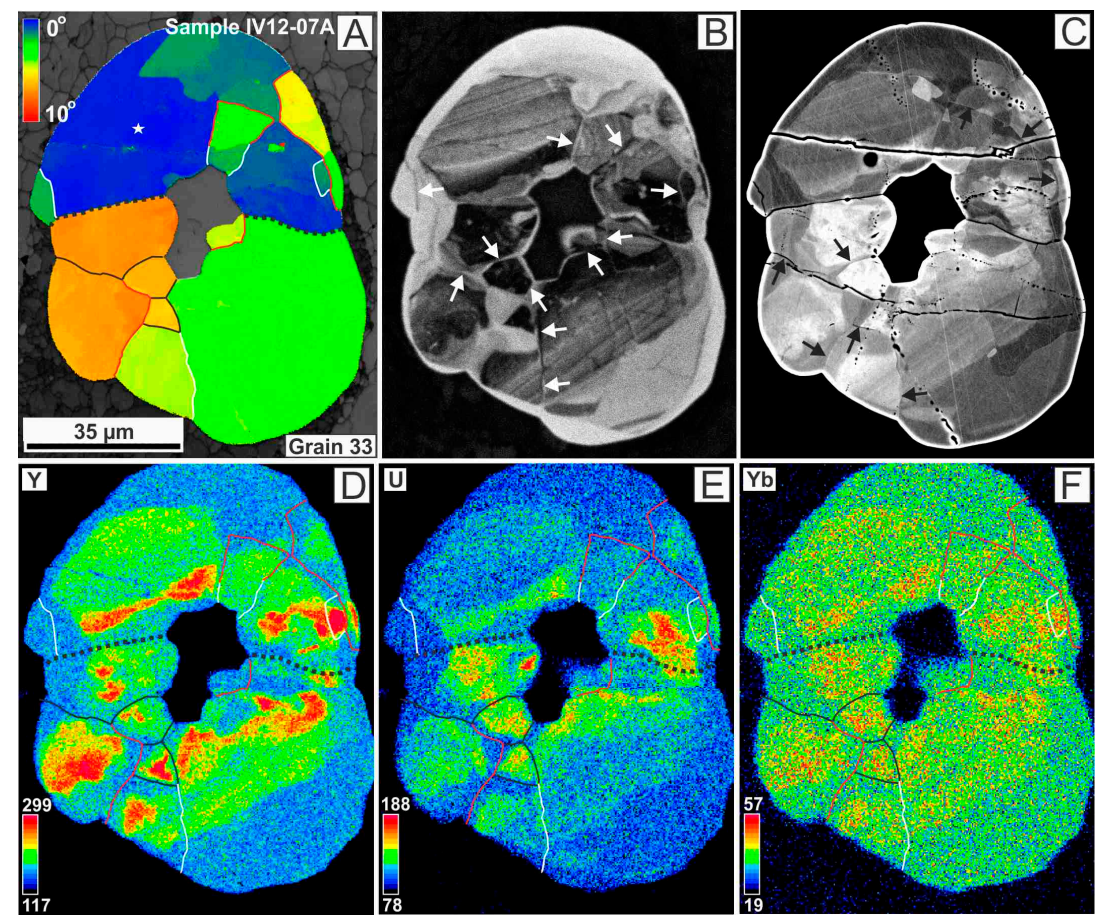

Figure 2. Images of the zircon grain 33, sample IV12-07A. (A) Cumulative misorientation EBSD map, showing the orientation of every data point with respect to a reference point (white star). Misorientation varies from 0 (blue) to $10^{\circ}$ (red). (B) Panchromatic CL image, arrows point to dark and bright features that spatially correspond to low angle boundaries. (C) BSE image of the grain, arrows as in B. (D) Qualitative chemical map of Y distribution derived with FEG-EMPA. (E) Qualitative chemical map of U distribution derived with FEG-EMPA. (F) Qualitative chemical map of $\mathrm{Yb}$ distribution derived with FEG-EMPA. Color-coding in D-F indicates the number of counts, different for each map. Superimposed lines in A, D, E, and F indicate positions of low-angle boundaries; white lines correspond to $<2^{\circ}$ of misorientation between the subgrains, red lines correspond to $2-5^{\circ}$ of misorientation, solid black lines correspond to $5-15^{\circ}$ of misorientation, thick black dotted lines highlight open fractures that produce misorientation.

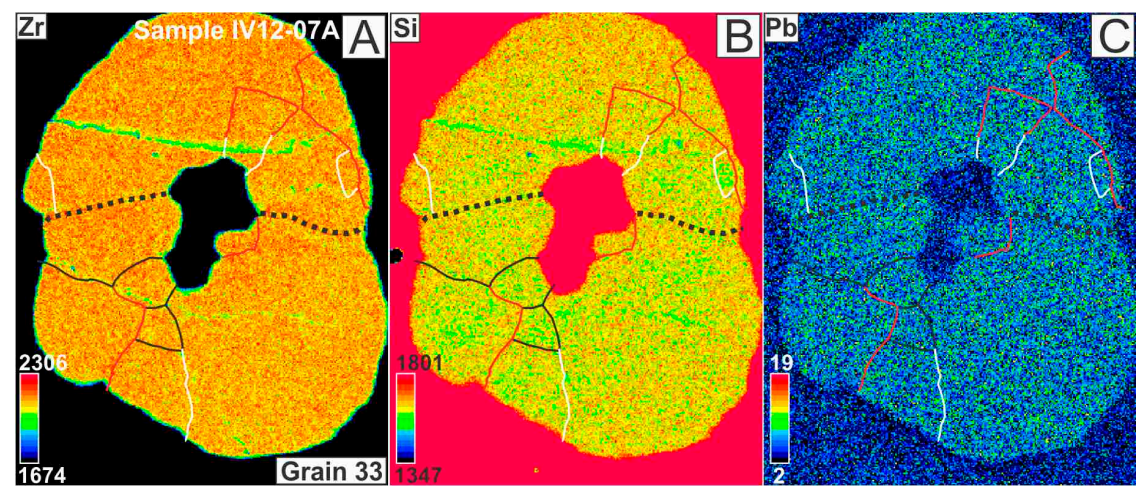

Figure 3. Additional chemical maps of the grain 33, sample IV12-07A. (A) Qualitative chemical map of $\mathrm{Zr}$ distribution. (B) Qualitative chemical map of Si distribution. (C) Qualitative chemical map of $\mathrm{Pb}$ distribution. Color-coding indicates the number of counts, different for each map. Lines as in Figure 2. 
A similar example of a polygranular zircon (grain 04b) from this sample is presented by [55] (their Figure 6). That grain has a CL-dark core, which is crosscut by bright linear features corresponding to low-angle boundaries. The latter can also be traced through the CL-bright rim. Chemical maps derived with the same method using EMPA show an Y- and U-enriched core that is being crosscut by linear features of Y- and U-depletion corresponding to low angle boundaries.

\subsection{Sample Suite BH12, Mylonitic and Foliated Granitic Gneisses, Western Tauern Window}

In this suite of samples, gneisses with various degrees of deformation reveal zircon grains with a polycrystalline appearance. Mylonitic orthogneiss (BH12-01) contains grain 06b, which is a resorbed zircon with three main detached fragments. Fragments have irregular shapes and polygranular appearance, with several "granules" building up each fragment (Figure 4A,B). Fragments have internal misorientation varying from 4 to $25^{\circ}$, which is mostly accommodated by granule boundaries (Figure 4B).

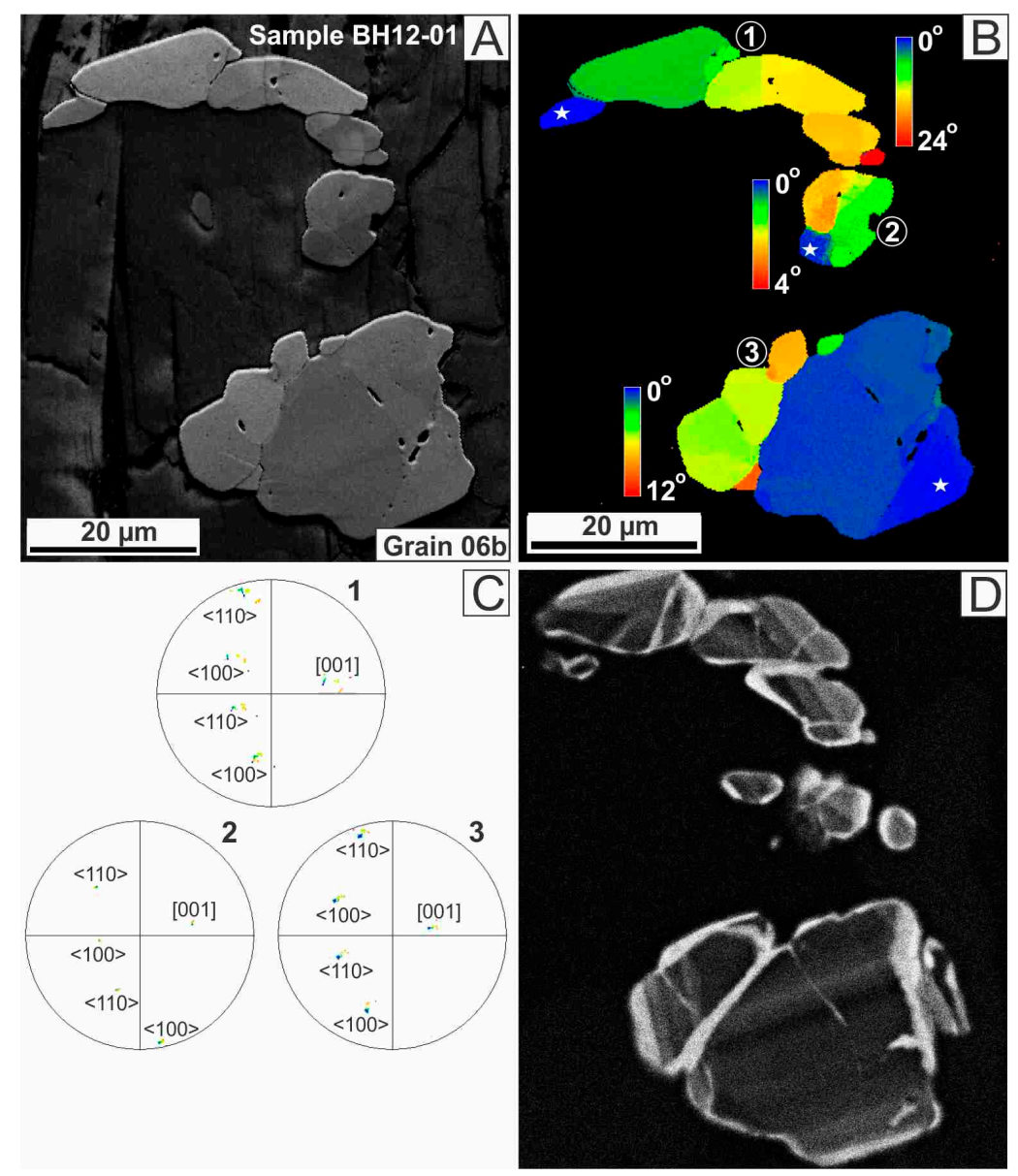

Figure 4. Data on the grain 06b, sample BH12-01. (A) EBSD pattern quality map revealing several detached fragments. (B) Cumulative misorientation or texture component EBSD map, showing the orientation of every data point with respect to a user-selected reference point (white star). Misorientation varies for each fragment according to the provided scales. (C) Lower hemisphere equal area projection pole figures, showing crystallographic axes [001], $<100>$ and $<110>$ orientation for each fragment. Color-coding as in corresponding EBSD maps in B. (D) Panchromatic CL image.

Crystallographic axes within each fragment scatter unsystematically, especially in those where cumulative misorientation is high (fragments 1 and 3, Figure 4C). In fragment 2, where misorientation does not exceed $4^{\circ}$, crystallographic axes seem to rotate around one of the $<100>$ axes. Fragments preserve initial concentric growth zoning in CL, where growth zones can be traced 
across boundaries of the granules (Figure 4D). Boundaries between granules crosscut fragments and are CL-bright; some contain trails of mineral inclusions (Figure 4A,D). Granules have various shapes and sizes, are sub-rounded to angular and elongated, and 3 to $25 \mu \mathrm{m}$ across. Most of the granules are strain-free, but some are internally strained.

Grain 36 is from the same mylonitic orthogneiss (sample BH12-01). It has a crescent shape and contains inclusion trails cutting across the grain in various directions (Figure 5A). In the EBSD map, these trails are coincident with low-angle boundaries. Cumulative misorientation of this grain does not exceed $4^{\circ}$, but the crystallographic axes show unsystematic dispersion or asterism (Figure 4B,C). In CL image, low-angle boundaries/inclusion trails appear as bright linear features that crosscut initial concentric growth zoning. As in the previous cases, CL-bright features are thicker than the corresponding low-angle boundaries. Thin CL-bright rim can be traced around the grain and also truncates the initial zoning (Figure 5D, lower left, upper right). CL image suggests that this grain is a fragment of a larger grain that had a CL-dark core visible at the left-hand side of the presented fragment.

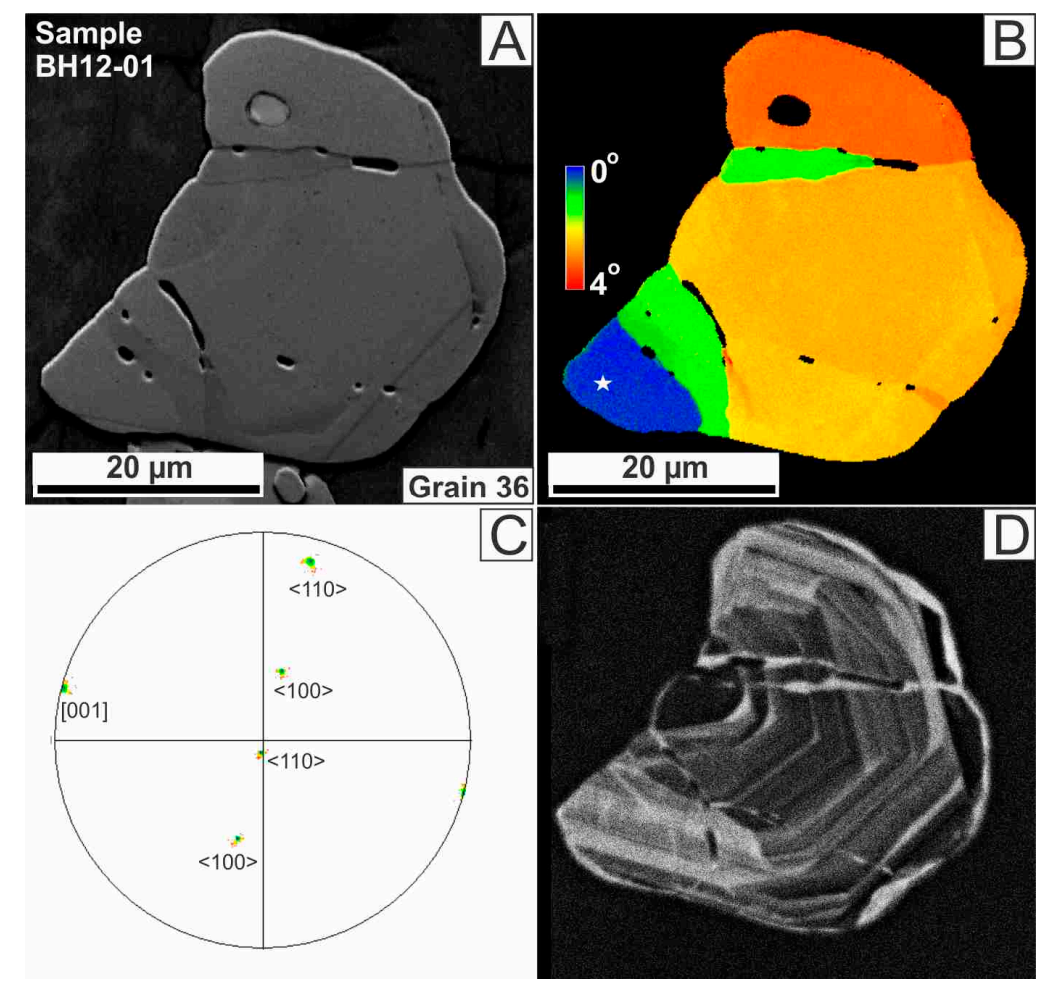

Figure 5. Data on the grain 36, sample BH12-01. (A) EBSD pattern quality map. (B) Cumulative misorientation or texture component EBSD map, showing the orientation of every data point with respect to a user-selected reference point (white star). Misorientation varies from 0 (blue) to $4^{\circ}$ (red). (C) Lower hemisphere equal area projection pole figure, showing unsystematic dispersion of the crystallographic axes [001], <100> and <110>. Color-coding as in the EBSD map in B. (D) Panchromatic CL image.

Grains 11 and 30 are from the mylonitic quartz-biotite orthogneiss (sample BH12-02). Grain 11 is elongated, grain 30 is equidimensional, and both have a polycrystalline texture with large mineral inclusions trapped between the granules (Figures 6 and 7). In the grain 11, inclusion trails are mostly coincident with the low-angle boundaries, whereas, in grain 30, only the largest inclusions are coincident and aligned with the low-angle boundaries. Crystallographic axes in both grains dispersed slightly, but their rotation is unsystematic (Figure 6C). 


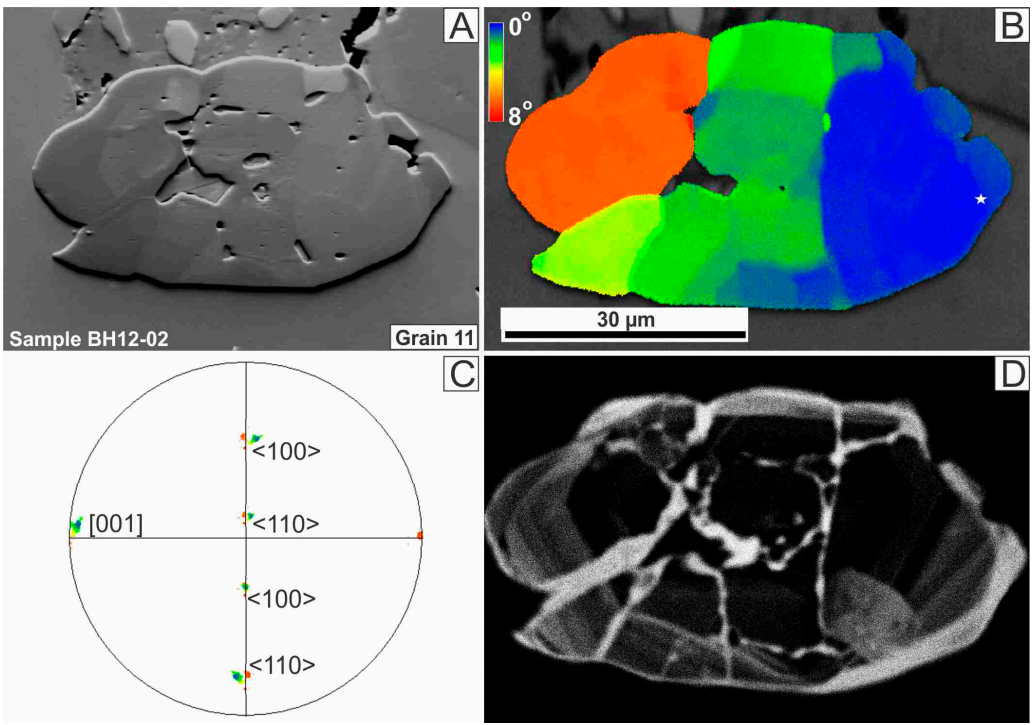

Figure 6. Data on the grain 11, sample BH12-02. (A) Orientation contrast image. (B) Cumulative misorientation or texture component EBSD map, showing the orientation of every data point with respect to a user-selected reference point (white star). Misorientation varies from 0 (blue) to $8^{\circ}$ (red). (C) Lower hemisphere equal area projection pole figure, showing unsystematic dispersion of the crystallographic axes [001], <100> and <110>. Color-coding as in the EBSD map in B. (D) Panchromatic CL image.
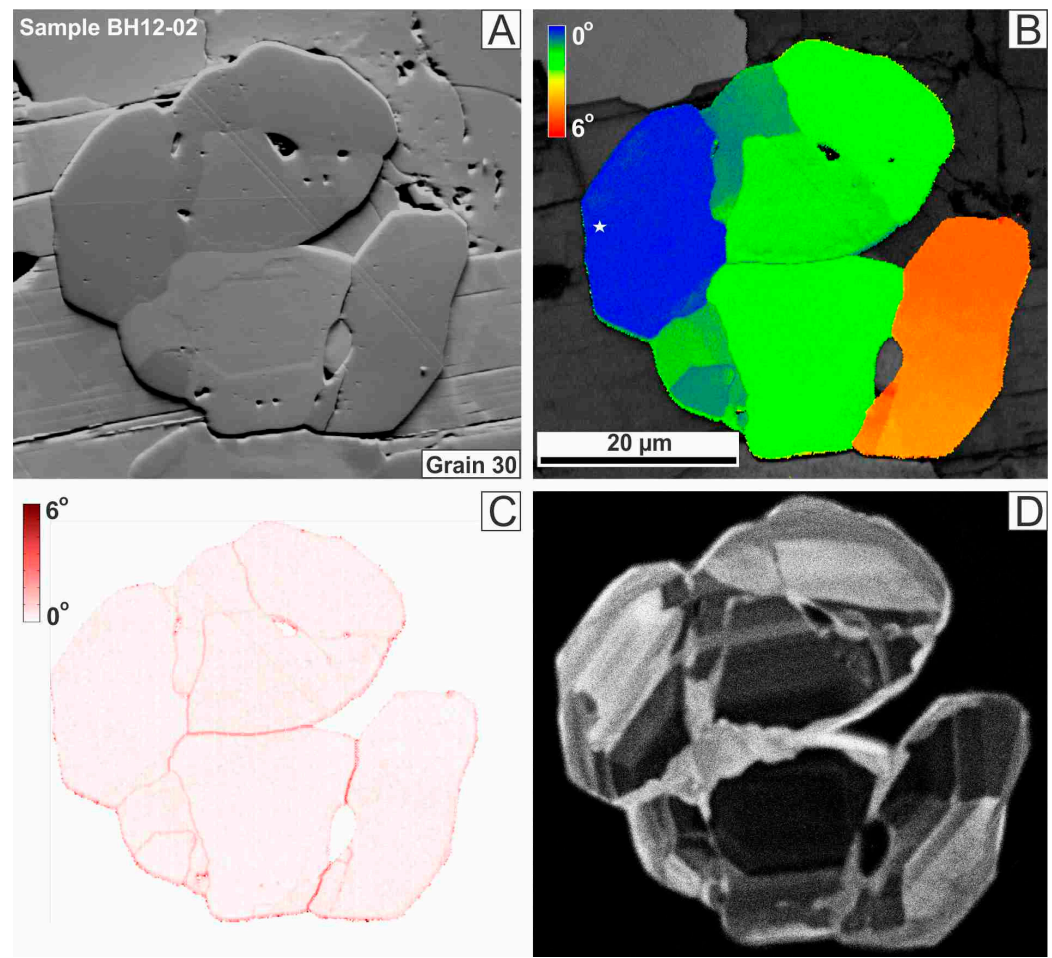

Figure 7. Data on the grain 30, sample BH12-02. (A) Orientation contrast image. (B) Cumulative misorientation EBSD map, showing the orientation of every data point with respect to a user-selected reference point (white star). Misorientation varies from 0 (blue) to $6^{\circ}$ (red). (C) Local misorientation EBSD map, showing misorientation of every pixel with respect to its neighbors. Local misorientation does not exceed $6^{\circ}$. The map shows low-angle boundaries that separate strain-free subgrains. (D) Panchromatic CL image. 
Cumulative misorientation does not exceed 6-8 (Figures 6B and 7B). Granules/subgrains are from 5 to $20 \mu \mathrm{m}$ in diameter and have irregular and angular shapes. In CL, bright linear features truncate the initial growth zoning and are coincident with, but significantly wider than the low-angle boundaries (Figures 6D and 7D). CL traces are particularly wide when corresponding to low-angle boundaries with higher misorientation (e.g., Figure 6B vs. Figure 6D). In the grain 30, the CL-bright central part is about $5 \mu \mathrm{m}$ thick and has jigsaw boundaries with the CL-dark material (Figure 7D), whereas corresponding low-angle boundary is sharp (Figure 7C).

One more example of a polygranular zircon from this sample is shown by [14] (their Figure 8). In that case, the fragments of a zircon grain are dispersed in the matrix, similar to what is shown here in Figure 4. Such dispersed aggregates were observed in the most deformed samples-BH12-01 and BH12-02, as well as in a strongly-foliated sample BH12-06.

Weakly-foliated orthogneiss (sample BH12-04) contains grain 01 (Figure 8), which is small (ca. $10 \mu \mathrm{m}$ in diameter), equidimensional and rectangular. The rectangle seems disturbed as if affected by shearing with the dextral sense of shear, where the left part of the grain was shifted upwards, and the right part of the grain was shifted downwards along the low-angle boundary between them (Figure 8B, arrows). Zircon has inclusion trails that do not necessarily coincide with the low-angle boundaries (Figure $8 \mathrm{~A}$ ).

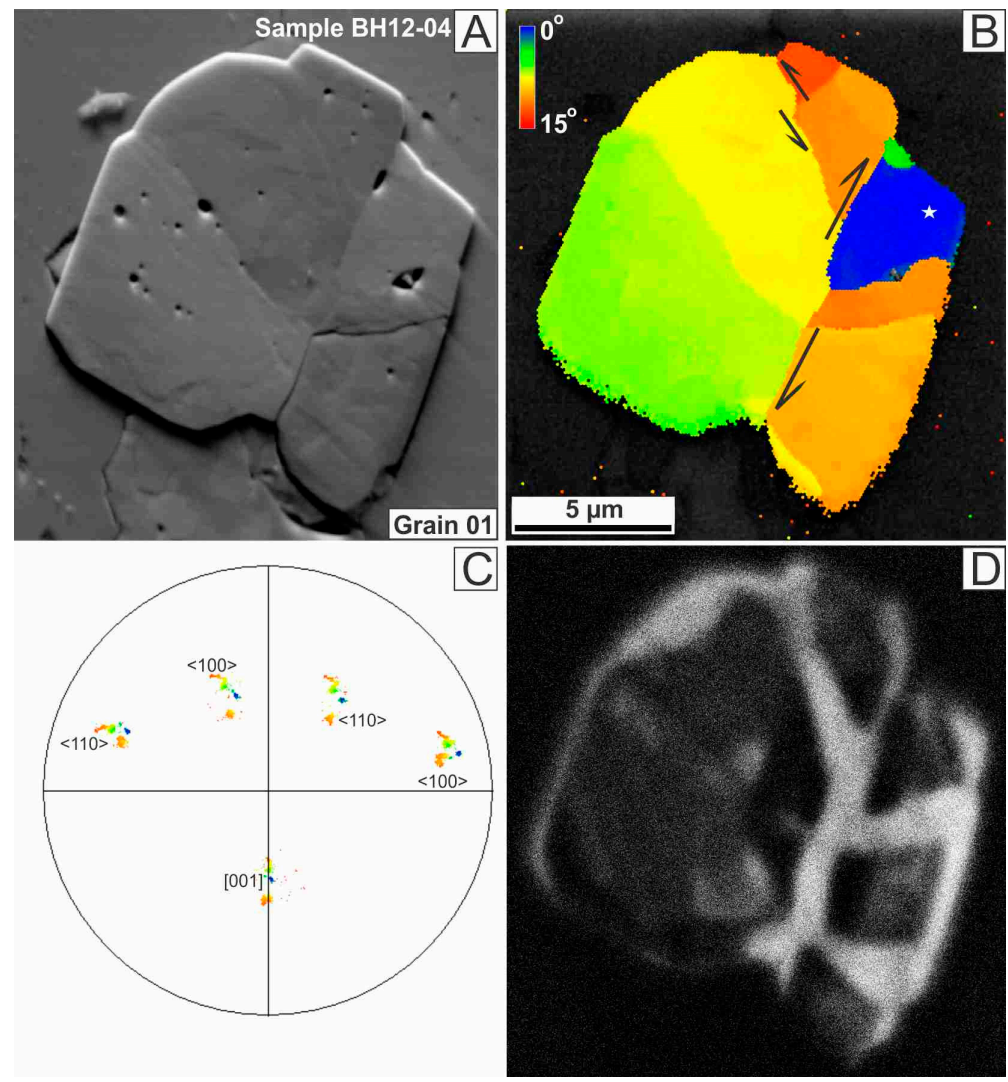

Figure 8. Data on the grain 01, sample BH12-04. (A) Orientation contrast image. (B) Cumulative misorientation EBSD map, showing the orientation of every data point with respect to a user-selected reference point (white star). Misorientation varies from 0 (blue) to $15^{\circ}$ (red). Arrows show the apparent relative movement of subgrains along low-angle boundaries. (C) Lower hemisphere equal area projection pole figure, showing unsystematic dispersion of the crystallographic axes [001], $<100>$ and $<110>$. Color-coding as in the EBSD map in B. (D) Panchromatic CL image.

Grain 01 has an internal misorientation of ca. $15^{\circ}$ that is accommodated by a network of low-angle boundaries (Figure $8 \mathrm{~B}$ ). Some of the low-angle boundaries are subparallel to each other, but the 
crystallographic axes are unsystematically dispersed (Figure 8C). Low-angle boundaries are coincident with broad (1-1.5 $\mu \mathrm{m}$ in width) CL-bright features, truncating CL zonation (Figure 8D).

Strongly-foliated orthogneiss (BH12-06) contains layers of biotite hosting multiple zircon grains (Figure 9A, bright phase), some of which are fractured, others appear polycrystalline (Figure 9B-F). These grains vary in shape and size, have internal misorientation of 3-10 ${ }^{\circ}$, which does not depend on the size of the grain (Figure 9B,D). Subgrain boundaries are bright in CL and crosscut growth zoning as thin lines. Studied grains show the unsystematic rotation of the crystallographic axes (Figure 9E). Grains 02a and 02c are, possibly, fragments of some larger pre-existing grains that were fractured and dispersed within the biotite layer.

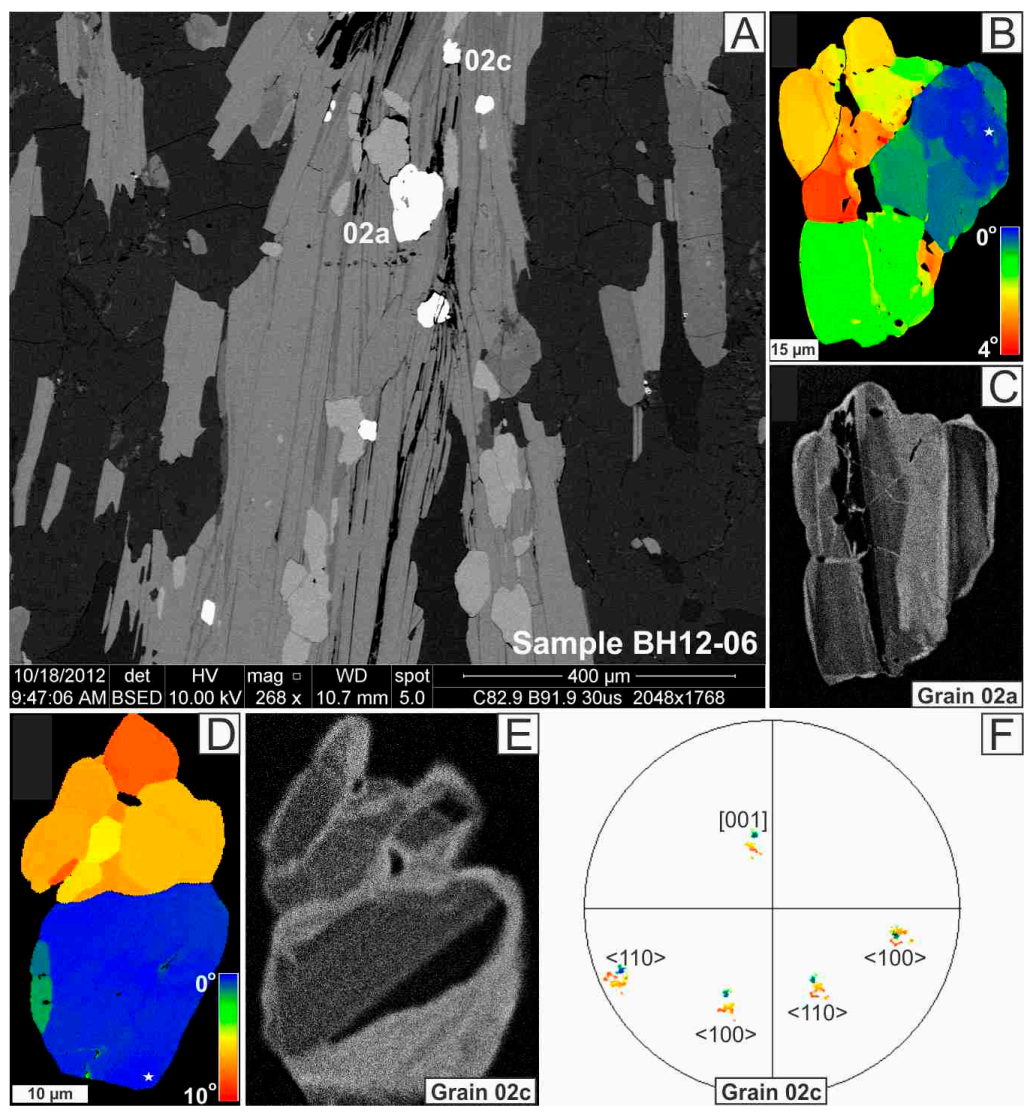

Figure 9. Data on the grain 02a and 02c, sample BH12-06. (A) BSE image showing the petrological context of the deformed zircon grains. (B) Cumulative misorientation or texture component EBSD map of the grain $02 \mathrm{a}$, showing the orientation of every data point with respect to a user-selected reference point (white star). Misorientation varies from 0 (blue) to $4^{\circ}$ (red). (C) Panchromatic CL image of the grain 02a. (D) Cumulative misorientation EBSD map of the grain 02c, showing the orientation of every data point with respect to a user-selected reference point (white star). Misorientation varies from 0 (blue) to $10^{\circ}$ (red). (E) Panchromatic CL image of the grain 02c. (F) Lower hemisphere equal area projection pole figure for the grain 02c, showing unsystematic dispersion of the crystallographic axes [001], $<100>$ and $<110>$. Color-coding as in the EBSD map in D.

Two more examples of polygranular zircon textures from the same sample (BH12-06) are shown in Figures 10 and 11, grains 08 and 11a accordingly. Both grains are composed of irregular subgrains/granules from $<5$ to $40 \mu \mathrm{m}$ in size. Cumulative misorientation is relatively small and reaches only $5^{\circ}$ in both grains (Figures 10B and 11B). Low-angle boundaries appear bright in CL and truncate initial growth zoning (Figures 10D and 11D). Grain 08 has inclusions that are often aligned with the subgrain boundaries. Both zircons appear to be fragments of larger grains. 


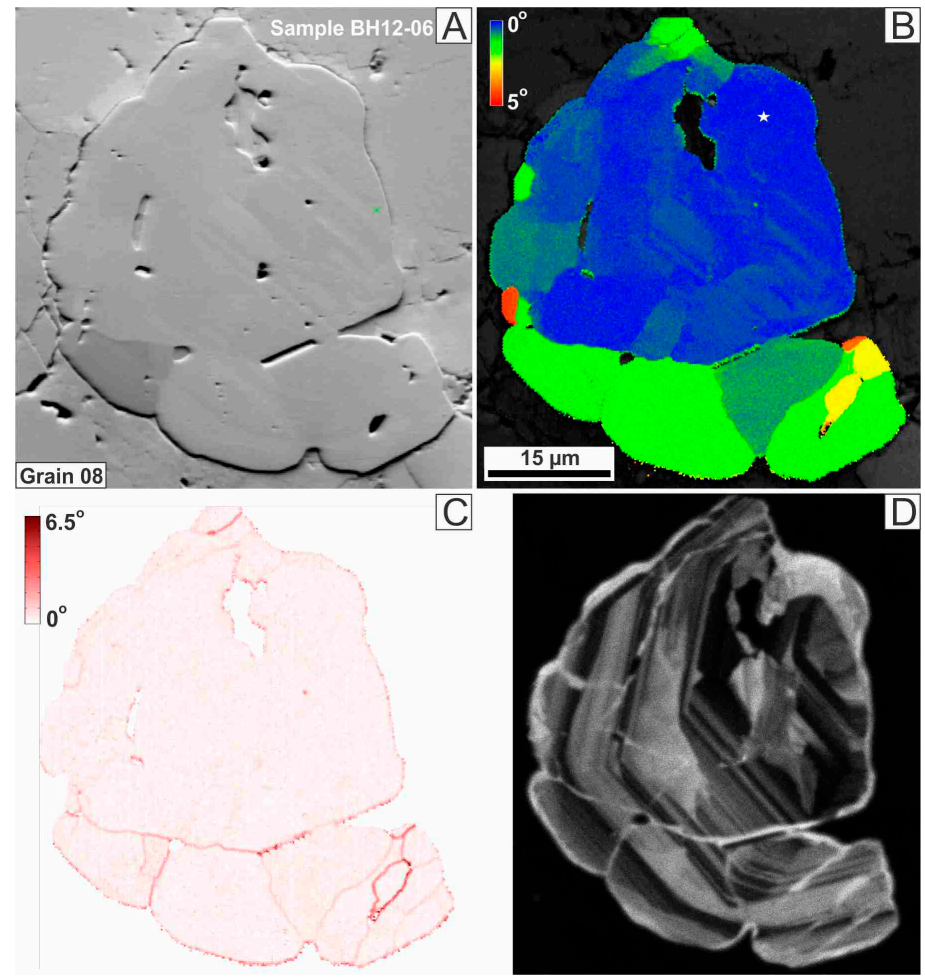

Figure 10. Data on the grain 08, sample BH12-06. (A) Orientation contrast image. (B) Cumulative misorientation EBSD map, showing the orientation of every data point with respect to a user-selected reference point (white star). Misorientation varies from 0 (blue) to $5^{\circ}$ (red). (C) Local misorientation EBSD map, showing misorientation of every pixel with respect to its neighbors. (D) Panchromatic CL image.

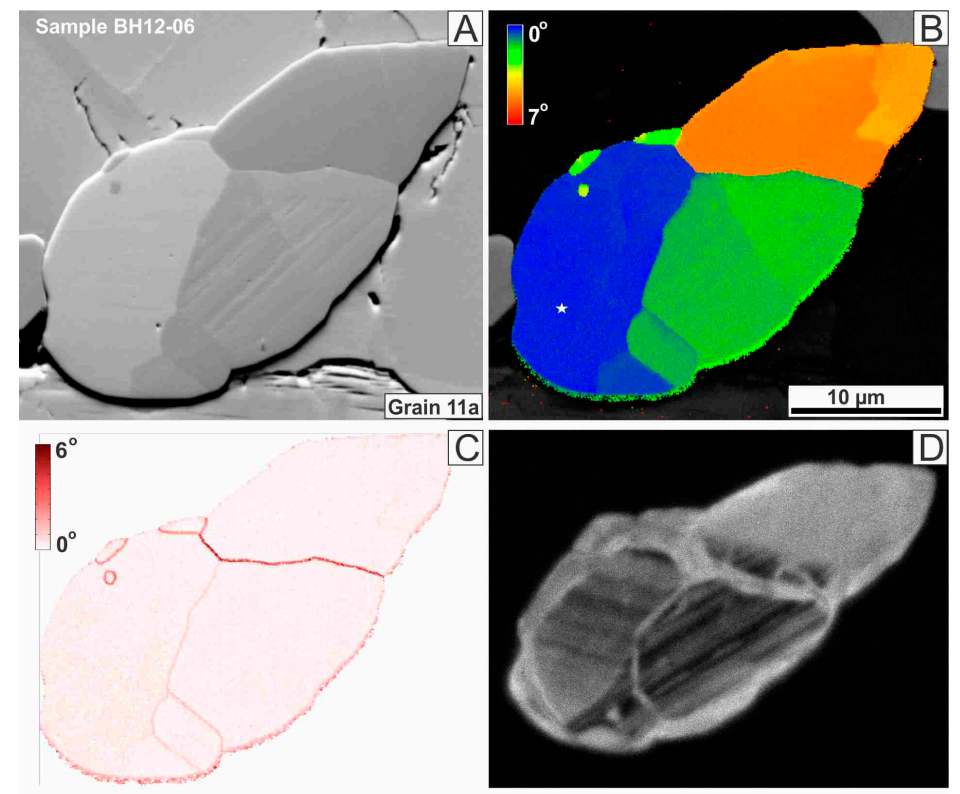

Figure 11. Data on the grain 11a, sample BH12-06. (A) Orientation contrast image. (B) Cumulative misorientation EBSD map, showing the orientation of every data point with respect to a user-selected reference point (white star). Misorientation within the grain varies from 0 (blue) to ca. $5^{\circ}$ (orange). (C) Local misorientation EBSD map, showing misorientation of every pixel with respect to its neighbors. (D) Panchromatic CL image. 
In the WTW samples, not only polycrystalline zircon formed due to metamorphic deformation is present. Many growth-related polycrystalline aggregates are observed (Figure 12). Such zircons often share one crystal face between the two grains and form L-shaped intergrowths (Figure 12A,B), T-shaped intergrowths (Figure 12C,D), and chains of crystals (Figure 12E,F). In such aggregates, each granule has its own concentric or sector zoning (Figure 12B).

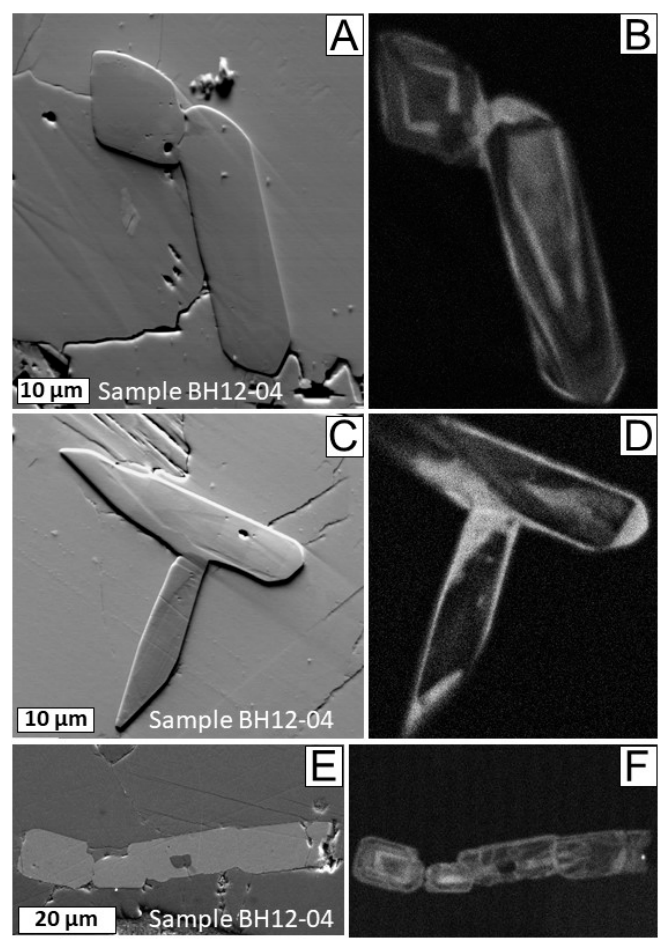

Figure 12. Examples of intergrown zircon crystals from the sample BH12-04. (A) Orientation contrast image of the two grains sharing a pyramidal face and forming an L-shaped aggregate. (B) CL image of an aggregate, shown in A. Each grain has its independent concentric zoning. (C) Orientation contrast image of the two grains forming a T-shaped aggregate. (D) CL image of the aggregate, shown in C. (E) SE image of a chain of three or four grains. (F) CL image of a growth aggregate, shown in E.

\section{Discussion}

\subsection{Various Types of Polygranular Zircon}

Zircon aggregates are not common in magmatic rocks. In granitoids, such as anatectic granites, zircon rarely occurs as twins and aggregates with several differently oriented grains (Figure 13). Occurrences of zircon polycrystalline aggregates in granitoids (Figure 13; [7-11]) is explained by the high viscosity conditions within the granitic magma during zircon nucleation. Viscous melt facilitates the formation of polycrystalline zircon aggregates by allowing several nucleation points to be located close to each other and to come into contact during subsequent growth, sharing a crystallographic plane $[7,56]$. In this case, individual zircon grains within the aggregate should have magmatic growth zoning (Figure 12B,D,F), if zoning is not destroyed by secondary fluid-induced processes, as shown by [11]. Euhedral shapes with well-defined faces characterize magmatic zircon in aggregates [9], which are sometimes rounded due to metamorphic overprint [6]. Such intergrown zircon grains occasionally demonstrate twin relationships or rotations at equal angles with respect to each other [7]. For example, [11] described an aggregate of four zircon grains from the aplite dike, each rotated at ca. $60^{\circ}$ to its neighbor (Figure 13D). In a different example, [11] show two intergrown crystals rotated at $65^{\circ}$ to each other and sharing one of the $<110>$ axes. Zircon growth aggregates of two or more interconnected crystals from the granitoid samples from WTW [11] (their Figure 4; and present 
study, Figure 12) are likely produced by specific growth conditions in granitic/aplitic protolith for the Zentralgneis.

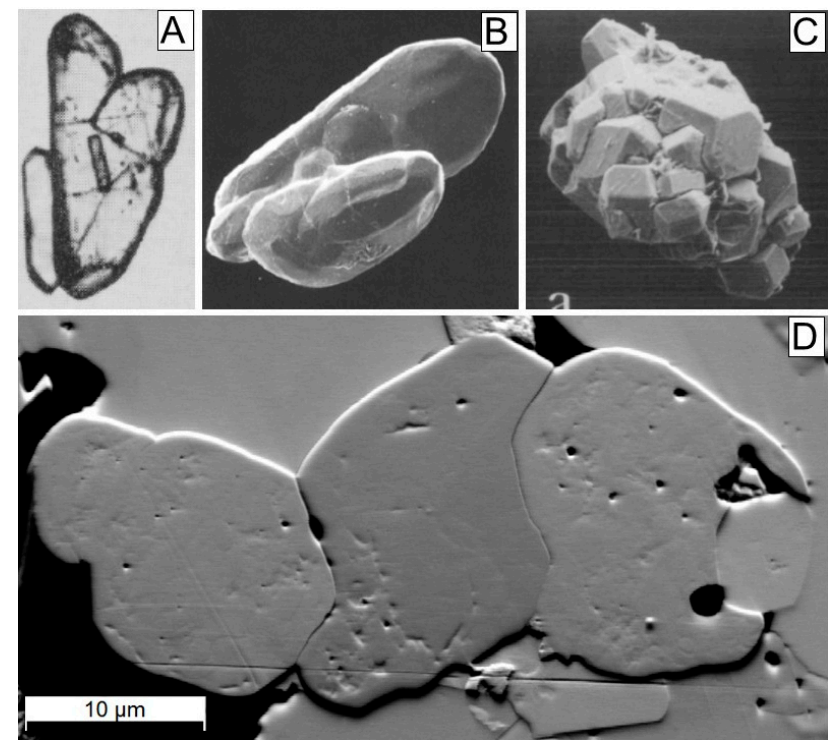

Figure 13. Examples of polycrystalline zircon from felsic magmatic settings. (A) Optical microscopy image after [7]. Twinned grain recovered from Precambrian granite gneisses from SW Greenland. (B) SEM image after [8]. Aggregate extracted from the metamorphosed trondhjemite from Massif Central, S France. (C) SEM image after [9]. Polycrystalline zircon aggregate was derived from the Suzhou granite pluton, E China. (D) Orientation contrast image of a chain of four zircon grains, after [11]. Grains are observed in situ in aplite dike, Western Tauern Window, S Austria.

However, far more common are zircon grains with polygranular textures formed in metamorphic and ductile deformation conditions (Figures 1-11). The properties of such polygranular grains do not differ depending on the deformation style of the host rocks: they are similar in comparatively broad shear zones (e.g., samples IV12-07A, BH12-01 and BH12-02) and in regionally-metamorphosed rocks (e.g., [13]; samples BH12-04 and BH12-06). In very localized shear zones, the character of polycrystalline grains can be slightly different [57]. Such textures are also described as "cauliflower" [6,12] and interpreted as grains being fractured and/or crystal-plastically deformed, for example, due to hydraulic fracturing or high differential stress during deformation [13,57]. The fragments are then corroded and subsequently healed/penetrated with metamorphic fluid. This mechanism explains a specific CL signature in parent grains, where initial growth zoning is crosscut by CL-bright linear features, thin or wide. These features-healed fractures and low-angle boundaries, infiltrated by fluid, are REE- and U-depleted (Figure 2), and similar in trace element composition to metamorphic rims. Fractures and low-angle boundaries facilitate trace element and isotopic exchange between the deformed zircon grain and metasomatic agents [55]. Inclusions of fine-grained matrix phases within healed fractures (e.g., Figure 5) suggest that the zircon was being fractured as the host rock was mylonitized. In some cases, such polygranular zircon crystals are overgrown by metamorphic rims and can lose prominent polycrystalline external appearance (e.g., Figure 1; [13]). In other cases, fragments remain detached from each other and are being unsystematically rotated, for example, by grain boundary sliding at increasing angles with respect to the parent grain (Figure 4; [14]; "D-grains" in [57]). The term "D-grains" (D for deformed) was introduced by [57], to describe cataclastically and crystal-plastically deformed zircon fragments that had been detached from large porphyroclasts and possess high internal misorientation, irregular grain boundaries and a disturbed CL signature [57]. Crystallographic axes of granules shown in present work reveal unsystematic scattering around parent orientation (Figures $4 \mathrm{C}$, 
$5 \mathrm{C}, 6 \mathrm{C}, 8 \mathrm{C}$ and $9 \mathrm{C})$, but the cumulative misorientation of the metamorphic polygranular aggregates is usually low (5-15 $5^{\circ}$ and up to $25^{\circ}$ in case of detached fragments, as in Figure 4).

As an additional type of polycrystalline metamorphic zircon, [57] described "Z-grains" that form from large zircon porphyroclasts and range from 50 to $100 \mu \mathrm{m}$ in diameter for each granule. Z-grains are assembled into aggregates with $120^{\circ}$ triple junctions, where each granule is concentrically-zoned in $\mathrm{CL}$ and has low internal strain (misorientation not exceeding $1^{\circ}$ ). Z-grains are randomly oriented, and their orientation is independent of a parent grain. Their chemical and isotopic composition also differs vastly from the parent porphyroclasts. The formation of Z-grains is explained by heterogeneous nucleation and growth during the retrograde stage of the deformation event, when Z-grains nucleate within the parent zircon lattice with increased dislocation density [57]. Considering the unusually large size of parent zircon porphyroclast $(>1 \mathrm{~mm})$ required to generate Z-grains, such textures are probably rather rare.

Polygranular zircon textures are often described from impact settings and found in a variety of impactites, such as suevite, diaplectic glass, tectites, impact glasses and impact melts, fallback and distal ejecta $[15,17,18,21,58-60]$. They are also described as "granular neoblastic" textures, assuming that the shock-induced granules are related to new nucleation and growth, and/or solid-state recrystallization $[25,28]$. Shock-related polygranular zircon textures were studied with EBSD, and multiple types were described:

(1) Polycrystalline domains that have fine granules $(<1 \mu \mathrm{m})$ and twin orientation of the domains with rotation by $65^{\circ}$ about [110] axis [61]. This textural type is said to be indicative of recrystallization under high shock pressure (20-30 GPa, [61]) and/or differential stress upon shock pressure release [62].

(2) Polycrystalline domains with fine granules (1-3 $\mu \mathrm{m})$ and specific crystallographic orientation of granules with respect to each other. Their c-axes are clustering around three mutually orthogonal directions, while the individual c-axis of each cluster is coincident with one of the [110] axes of each other cluster. Such orientation is said to indicate phase transformation from high-pressure zircon polymorph reidite, so-called "former reidite in granular neoblastic" ("FRIGN") zircon (Figure 14C) $[26,28,29,61,63]$. This polycrystalline type might be indicative of high shock pressure (ca. 30-35 GPa) and subsequent heating $\left(>1200{ }^{\circ} \mathrm{C}\right)$, which allowed for zircon to transform to reidite and for the reidite to revert back to zircon [64]. Such recrystallized grains may show remnant initial growth zoning, while the individual neoblasts, in turn, contain metamict cores and well-crystalline rims [30].

(3) Fine granules with "FRIGN" orientation and micro-inclusions of baddeleyite $[24,25,29,65]$. This texture is believed to indicate not only zircon-reidite-zircon transformation but also zircon decomposition at high temperature into $\mathrm{Zr}$ and Si oxides.

(4) Domains composed of small granules with "FRIGN" orientation, mixed with granules and/or lamellae of reidite $[26,65]$. This texture indicates high shock pressure with incomplete post-impact high-temperature annealing.

(5) Polycrystalline domains composed of fine granules with no systematic orientation $[28,30]$. These can be grains with distorted "FRIGN" zircon signature or a different type of shock-induced texture.

(6) Small granules (ca. $5 \mu \mathrm{m}$ ) with one orientation (Figure 14D) [28]. This textural type was observed in one grain, which might be unrelated to shock deformation, and could be metamorphic or related to shearing, pre- or post-impact, or affected by some long-term post-impact deformation; therefore, this type will not be taken into account further.

(7) Large granules $(10-100 \mu \mathrm{m})$ with concentric zoning [22,23,27,66], which nucleate inside the parent grain (Figure 14E-H). In some cases, granules cluster together and form triple junctions [23,67]. In other cases, they are spread randomly within the host grain [27]. Such neoblasts likely grew 
post-impact, due to elevated temperatures maintained after the shock event, for example, by the exposure to superheated impact melt [22,27].

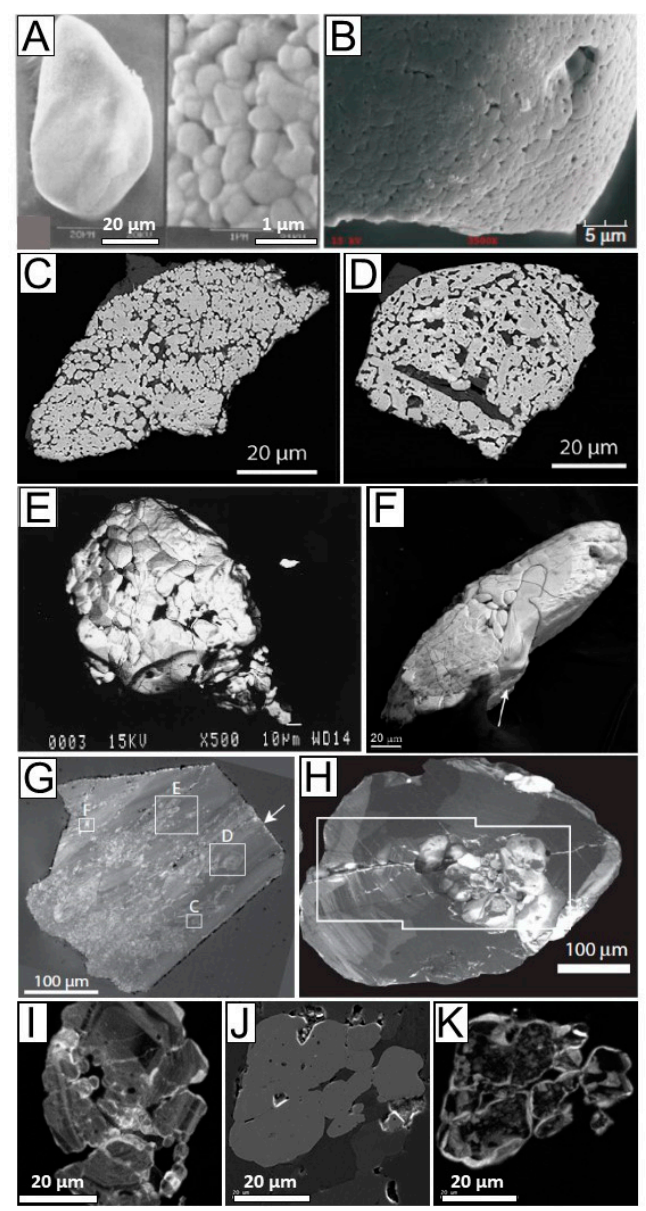

Figure 14. Examples of polygranular zircon from impact and non-impact metamorphic settings, showing that they are easy to confuse. (A) SEM image of rounded polycrystalline zircon from tektite, Indochina, with its surface enlarged, after [16]. (B) SEM image of the surface of polycrystalline zircon from the K-T boundary in Spain, after [19]. (C) BSE image of zircon with small granules with "FRIGN" orientation from impact melt, Lappajärvi impact structure, after [28]. (D) BSE image of zircon grain composed of similarly-oriented small granules, source as in C. (E) and (F) SEM images of zircon composed of large randomly-oriented neoblasts from foliated norite, Vredefort impact structure, after [66] and [22] accordingly. (G) CL image of a zircon grain with large randomly-oriented granules, from the impact melt in Sudbury impact structure, after [27]. (H) CL image of zircon with a polygranular central domain with large granules, from the Vredefort impact structure (detrital), after [67]. (I) CL image of polygranular zircon from metamorphic settings, sample BH12-06 (present study). Compare to H. (J) SE image of zircon grain from metamorphic settings, sample BH12-06 (present study). (K) CL image of a grain shown in $\mathrm{J}$.

Many of these types (1)-(7) can be easily confused using only "traditional" SEM imaging such as SE, BSE, and CL (Figure 14A-H). They can also be confused with metamorphic textures in zircon (Figure 14I-K; [23,36]). At the same time, each of these polycrystalline types (1)-(7) indicates distinct impact and post-impact conditions of the zircon environment, such as pressure and temperature vs. time [65]. Therefore, polygranular neoblastic zircon is a tool for the reconstruction of deformation regimes [30], as well as for isotopic dating of impact events [27-29]. Thus, it is important to recognize and correctly interpret polycrystalline textures in zircon, providing the potential to discover new types. To make reasonable interpretations, crystallographic mapping (EBSD) is critical in many cases. 


\subsection{Key Differences between Textures Observed in Polygranular Zircon Types}

In most cases, polygranular metamorphic zircon can be distinguished from igneous polycrystalline aggregates using the CL signature and crystallographic orientation. In deformed zircon, the CL signature of every granule indicates a fragment of a preexisting grain (Figures $2 \mathrm{~B}, 4 \mathrm{D}$ and $5 \mathrm{D}$ ), and orientation is scattered around the orientation of a parent grain (Figures 4C, 5C, 6C and 8C). In growth (magmatic) aggregates, each granule has a CL zonation of an independent grain (Figure 12B,C,F), if zonation is preserved. The orientation of each grain in growth aggregates is also independent, sometimes making systematic angles with neighbors (such as $60^{\circ}, 65^{\circ}$ or $90^{\circ},[7,11]$ ). These systematic angles cannot be observed in rotated fragments of grains, deformed in metamorphic settings or ductile shear zones. In the case of Z-grains [57], aggregates that are deformed in a shear zone can indeed look like magmatic intergrowths with their $120^{\circ}$ triple junctions, independent orientation and oscillatory zoning of each granule. However, Z-grains are rather rare, and where described, occur within the contours of their parent grain and in proximity to D-grains in thin sections [57]. D-grains are clearly a product of deformation and could be used as an indicator of the formation mechanism of the adjacent Z-grains.

Tectonically-deformed zircon resulting in polycrystalline textures also differs from shock-related polygranular zircon. Fine-grained shocked types (1)-(6) are composed of much smaller granules than the metamorphic granules, which usually are widespread in size. Shock-recrystallized polycrystalline aggregates often reveal either systematic orientation (such as FRIGN zircon signature) or completely unsystematic orientation, opposite to scattering of metamorphic granules around some parent orientation. Furthermore, fine-grained shock aggregates often contain inclusions indicative of high-pressure and high-temperature conditions, such as baddeleyite and reidite phases, absent in metamorphic aggregates. Large granules type (7) have concentric growth zoning within each granule [27], whereas metamorphic granules usually represent fragments of one preexisting zoned grain (Figures 7D, 9C,E, 10D and 11D). Nevertheless, it can be difficult to distinguish shock- recrystallized type (7) with tectonically-deformed grains, as the CL signature is not always clear (Figure 14G,H vs. Figure 14I). In that case, EBSD analyses should show the independent orientation of every granule for the shock- recrystallized aggregates and scatter around one direction for the tectonically-induced aggregates or no scattering at all [36]. Specifically, Z-shaped metamorphic aggregates can be confused with shock- recrystallized polygranular aggregates type (7), as both are concentrically-zoned, have triple junctions, randomly- and independently-oriented, and found within the boundaries of the parent grain $[23,27,57]$. To distinguish between Z-grains and shock-related type (7), the proximity of Z-grains to D-grains can be used in thin sections, as well as mineral inclusions such as ilmenite trapped between Z-grains. However, taking into account all the morphological similarities, it is likely that their formation mechanisms are similar, and it is possible that the Z-grains can be formed during post-impact metamorphic overprint, representing impact-induced type (7) at the same time.

Igneous aggregates can be confused with impact-related aggregates type (7). However, in most cases, impact-related aggregates occur within the parent grain, replacing it partially or entirely (Figure 14E,G,H). In contrast, igneous aggregates have a shape of a druse or a cluster of intergrown crystals (Figure 13). Still, they can be fairly similar (Figure 13A vs. Figure 14F), and caution should be taken when interpreting the aggregate's origin. Igneous intergrowths of zircon could also be formed from the impact-generated melts and yield the isotopic age of an impact event.

\section{Conclusions and Recommendation}

Polygranular or polycrystalline zircon can be a useful tool for the isotopic dating of magmatic and deformation events $[22,23,57,66]$. However, as demonstrated above, polygranular zircon can be produced in a variety of unrelated magmatic, metamorphic, and impact settings. Often, genetically different polycrystalline types have only very subtle textural differences, not easily revealed by traditional SEM-CL imaging of zircon. Therefore, in many cases, the application of the EBSD technique is recommended. The properties of different genetic types of polycrystalline zircon grains are summarized in Table 1. 
Table 1. Characteristics of various polycrystalline zircon types.

\begin{tabular}{|c|c|c|c|c|c|c|}
\hline \multirow{3}{*}{$\begin{array}{l}\text { Polycrystalline Zircon } \\
\text { Characteristics }\end{array}$} & \multicolumn{6}{|c|}{ Genetic Types of Zircon } \\
\hline & \multirow{2}{*}{ Igneous } & \multirow{2}{*}{$\begin{array}{l}\text { From Regional Metamorphic/Metasomatic } \\
\text { Settings and Broad Shear Zones }\end{array}$} & \multicolumn{2}{|c|}{ Related to a Localized Shear-Zone, after [57] } & \multicolumn{2}{|c|}{ Impact-Related } \\
\hline & & & D-Grains & Z-Grains & $\begin{array}{l}\text { Grains with Fine Granules } \\
\text { (Types 1-5) }\end{array}$ & $\begin{array}{c}\text { Grains with Large Granules } \\
\text { (Type 7) }\end{array}$ \\
\hline Grain shape & $\begin{array}{l}\text { Subhedral to euhedral, in } \\
\text { metamorphosed } \\
\text { rocks-(sub)rounded }\end{array}$ & $\begin{array}{l}\text { Cauliflower, crescent shapes of the aggregate; } \\
\text { individual granules vary }\end{array}$ & $\begin{array}{l}\text { Elongated to equidimensional } \\
\text { irregularly-shaped }\end{array}$ & Equidimensional, polygonal & $\begin{array}{l}\text { Subhedral, rounded or } \\
\text { slightly elongated }\end{array}$ & $\begin{array}{l}\text { Euhedral, elongated or } \\
\text { equidimensional }\end{array}$ \\
\hline Grain size & $\begin{array}{l}\text { 5-50 } \mu \mathrm{m} \text { for individual } \\
\text { grain in an aggregate }\end{array}$ & $\begin{array}{l}\text { Parent grains are }<10->500 \mu \mathrm{m} \text { in length; } \\
\text { resulting granules are }<1->30 \mu \mathrm{m}\end{array}$ & $\begin{array}{l}\text { Range from very small }<2 \\
\text { to } 100-150 \mu \mathrm{m}\end{array}$ & $50-100 \mu \mathrm{m}$ & $0.5-3 \mu \mathrm{m}$ & $10-100 \mu \mathrm{m}$ \\
\hline Type of boundaries & Sharp grain boundaries & $\begin{array}{l}\text { Low- or high-angle subgrain boundaries, } \\
\text { healed fractures with bright haloes }\end{array}$ & $\begin{array}{l}\text { Serrated and irregular grain } \\
\text { boundaries }\end{array}$ & $\begin{array}{c}\text { Polygonal } \\
\text { grain boundary network with } 120^{\circ} \\
\text { triple junctions indicative of } \\
\text { textural equilibrium }\end{array}$ & $\begin{array}{l}\text { Grain boundaries between the } \\
\text { granules }\end{array}$ & $\begin{array}{l}\text { Sharp grain boundaries } \\
\text { between the neoblasts and } \\
\text { parent grain, triple junctions } \\
\text { between the neoblasts }\end{array}$ \\
\hline $\begin{array}{l}\text { Internal misorientation } \\
\text { type }\end{array}$ & $\begin{array}{l}\text { No internal } \\
\text { misorientation }\end{array}$ & $\begin{array}{l}\text { Cumulative misorientation }<3-25^{\circ} \text { by } \\
\text { low-angle boundaries or free dislocations }\end{array}$ & $\begin{array}{l}\text { Low-angle boundaries and } \\
\text { high-lattice distortions of } 2-8^{\circ} \\
\text { within a single grain }\end{array}$ & $\begin{array}{l}\text { Low internal strain (misorientation } \\
\left.\text { not exceeding } 1^{\circ}\right)\end{array}$ & No internal misorientation & No internal misorientation \\
\hline $\begin{array}{l}\text { Orientation with } \\
\text { respect to each other or } \\
\text { a parent grain } \\
\end{array}$ & $\begin{array}{c}\text { Twin relationships } \\
{[7,11,68] \text { or disorientation }} \\
\text { at high angles [11] }\end{array}$ & $\begin{array}{c}\text { Unsystematic scattering around parent } \\
\text { orientation with low total misorientation } \\
\left(5-15^{\circ}\right)\end{array}$ & $\begin{array}{l}\text { Mostly random orientation and no } \\
\text { relationship to the } \\
\text { porphyroclast }\end{array}$ & $\begin{array}{l}\text { Little affinity to a parent grain, } \\
\text { random orientation }\end{array}$ & $\begin{array}{l}\text { Random orientation, three } \\
\text { clusters of orthogonal c-axes, } \\
\text { twin orientation } \\
\end{array}$ & $\begin{array}{l}\text { Random orientation, } \\
\text { independent of the host grain }\end{array}$ \\
\hline Inclusions & $\begin{array}{l}\text { Magmatic rock-forming } \\
\text { or accessory minerals } \\
\text { (e.g., apatite) }\end{array}$ & $\begin{array}{l}\text { Fine-grained matrix phases within } \\
\text { healed fractures }\end{array}$ & $\begin{array}{l}\text { Rutile and ilmenite, smaller zircon } \\
\text { grains (Z-grains) }\end{array}$ & $\begin{array}{l}\text { Ilmenite trapped between the } \\
\text { Z-grains }\end{array}$ & Reidite, baddeleyite & None \\
\hline CL signature & $\begin{array}{l}\text { Individual zircon grains } \\
\text { within the aggregate have } \\
\text { magmatic growth zoning }\end{array}$ & $\begin{array}{l}\text { Initial concentric growth zoning is crosscut by } \\
\text { CL-bright linear features; in some cases, } \\
\text { overgrown by CL-bright, Y a and REE-depleted } \\
\text { metamorphic rims }\end{array}$ & $\begin{array}{l}\text { Bright CL signature, closely linked } \\
\text { to the deformation features }\end{array}$ & $\begin{array}{l}\text { Concentric, slightly diffuse } \\
\text { growth zoning }\end{array}$ & $\begin{array}{l}\text { Concentric with dark cores and } \\
\text { bright rims; the initial growth } \\
\text { zoning of the parent grain is } \\
\text { preserved }\end{array}$ & $\begin{array}{l}\text { Concentric grown zoning as } \\
\text { in igneous grains }\end{array}$ \\
\hline Host rocks & Predominantly granitoids & $\begin{array}{l}\text { Metaigneous and metasedimentary foliated } \\
\text { (ultra)mylonites, peak conditions at } \\
\text { amphibolite facies }\end{array}$ & $\begin{array}{l}\text { High-strain mylonitic zone in the } \\
\text { granulite facies } \\
\text { meta-anorthositic body }\end{array}$ & $\begin{array}{l}\text { High-strain mylonitic zone in the } \\
\text { granulite facies } \\
\text { meta-anorthositic body }\end{array}$ & $\begin{array}{l}\text { Suevite, diaplectic glass, tectites, } \\
\text { impact glasses and impact melts, } \\
\text { fallback and distal ejecta }\end{array}$ & Impact melt rocks \\
\hline $\begin{array}{l}\text { Formation mechanism } \\
\text { and temperature }\end{array}$ & $\begin{array}{l}\text { Several nucleation points } \\
\text { close to each other come } \\
\text { into contact; } \\
\text { crystallization } \\
\text { temperature of granitoids }\end{array}$ & $\begin{array}{l}\text { Fracturing and/or crystal-plastic deformation, } \\
\text { e.g., due to hydraulic fracturing or high } \\
\text { differential stress. The fragments are corroded } \\
\text { and sometimes subsequently healed with } \\
\text { metamorphic fluid. Peak metamorphic } \\
\text { temperatures: } 550-650^{\circ} \mathrm{C}\end{array}$ & $\begin{array}{l}\text { Fragmentation with fragment } \\
\text { detachment from each other. } \\
\text { Fragments are being } \\
\text { unsystematically rotated by grain } \\
\text { boundary sliding. Deformation } \\
\text { temperature ca. } 620-6900^{\circ} \mathrm{C}\end{array}$ & $\begin{array}{l}\text { Heterogeneous nucleation/growth } \\
\text { caused by a deformation-induced } \\
\text { influx of fluids at the retrograde } \\
\text { stage of deformation. Nucleate } \\
\text { within the parent lattice with high } \\
\text { dislocation density. (De)formation } \\
\text { temperature ca. } 725 \text { to } 750^{\circ} \mathrm{C}\end{array}$ & $\begin{array}{l}\text { Recrystallization under high } \\
\text { pressure-temperature conditions: } \\
\text { solid-state or through melting. } \\
\text { High impact temperatures: } \\
>1100-1200^{\circ} \mathrm{C}[65]\end{array}$ & $\begin{array}{l}\text { Possibly, grew post-impact, } \\
\text { due to elevated temperatures } \\
\text { maintained after initial shock; } \\
\text { could be similar to Z-grains. } \\
\text { High post-impact } \\
\text { temperatures of ca. } 1000^{\circ} \mathrm{C}\end{array}$ \\
\hline U-Pb dating & $\begin{array}{l}\text { Age of crystallization of } \\
\text { the igneous melt }\end{array}$ & $\begin{array}{l}\text { Age of CL-bright metamorphic areas results in } \\
\text { the age of regional metamorphism [4], the } \\
\text { detrital cores might be partially reset [55] }\end{array}$ & $\begin{array}{l}\text { Have a large } \\
\text { age spread, distorted } \\
\text { isotopic system }\end{array}$ & $\begin{array}{l}\text { Directly date the metamorphic } \\
\text { reworking, complete resetting of the } \\
\text { U-Pb system }\end{array}$ & $\begin{array}{l}\text { May or may not yield the age of } \\
\text { an impact; partial or complete } \\
\text { resetting of radiogenic } \mathrm{Pb}\end{array}$ & $\begin{array}{l}\text { Age of an impact event; } \\
\text { complete resetting of } \\
\text { radiogenic } \mathrm{Pb}\end{array}$ \\
\hline
\end{tabular}


Besides, the nature of an impact process is such that it can produce magmatic rocks [69-72] and induce metamorphic processes, especially in large impact structures [73-76]. Igneous polycrystalline aggregates can be crystallized from impact-generated melts, whereas metamorphic Z-grains can be theoretically produced within thermally-overprinted impactites. Therefore, when using polygranular zircon grains for isotopic dating of a geological event, ambiguity can be present. In that case, isotopic analyses of other minerals and rocks should be used to support the obtained ages [23].

Supplementary Materials: The following are available online at http://www.mdpi.com/2075-163X/10/5/469/s1: EBSD datasets.

Funding: The analyses were funded by the University of Vienna (doctoral school "DOGMA," project IK 052). This work is produced within the frames of interdisciplinary project GRAVITAS ("Geological Research and Analysis of Vredefort Impact with Timely Anthropological Studies"), the grant received from the Directorate for Research Development, University of the Free State, 2019-2020.

Acknowledgments: The author is grateful to Rainer Abart, Christian Auer, Claudia Beybel, Franz Biedermann, Bernhard Grasemann, Sigrid Hrabe, and Urs Klötzli. I am also thankful to the Geological Survey of Austria for access to the SEM; to the Helmholz Centre Potsdam in Germany for access to the FEG-EMPA, and specifically to Dieter Rhede, who assisted with the data collection and plotting. The author acknowledges access to the Laboratory for scanning electron microscopy and focused ion beam applications, Faculty of Earth Sciences, Geography and Astronomy at the University of Vienna (Austria). Gerlinde Habler assisted with the EBSD data collection. I am thankful to Annette Wilkinson and Liesl van der Westhuizen for their support in proof-reading. The Postgraduate School and the Centre for Teaching and Learning, UFS, are acknowledged for organizing the writing retreats that facilitated me in writing this paper. Two anonymous reviewers and the academic editor are thanked for their constructive and helpful comments and suggestions.

Conflicts of Interest: The authors declare no conflict of interest. The funders had no role in the design of the study; in the collection, analyses, or interpretation of data; in the writing of the manuscript, or in the decision to publish the results.

\section{References}

1. Davis, D.W.; Williams, I.S.; Krogh, T.E. Historical development of zircon geochronology. In Zircon, 1st ed.; Hanchar, J.M., Hoskin, P.W.O., Eds.; Mineralogical Society of America and Geochemical Society: Chantilly, VA, USA, 2003.

2. Corfu, F. Uranium-Lead, Zircon. In Encyclopedia of Scientific Dating Methods; Rink, W.J., Thompson, J.W., Eds.; Springer: Dordrecht, South Africa, 2013. [CrossRef]

3. Klötzli, U.S.; Sinigoi, S.; Quick, J.E.; Demarchi, G.; Tassinari, C.C.G.; Sato, K.; Günes, Z. Duration of igneous activity in the Sesia Magmatic System and implications for high-temperature metamorphism in the Ivrea-Verbano deep crust. Lithos 2014, 206-207, 19-33. [CrossRef]

4. Kusiak, M.A.; Kovaleva, E.; Wirth, R.; Klötzli, U.; Dunkley, D.J.; Yi, K.; Lee, S. Lead oxide nanospheres in seismically deformed zircon grains. Geochim. Cosmochim. Acta 2019, 262, 20-30. [CrossRef]

5. Pupin, J.P. Zircon and granite petrology. Contrib. Mineral. Petrol. 1980, 73, 207-220. [CrossRef]

6. Corfu, F.; Hanchar, J.M.; Hoskin, P.W.O.; Kinny, P. Atlas of zircon textures. In Zircon, 1st ed.; Hanchar, J.M., Hoskin, P.W.O., Eds.; Mineralogical Society of America and Geochemical Society: Chantilly, VA, USA, 2003.

7. Jocelyn, J.; Pidgeon, R.T. Examples of twinning and parallel growth in zircons from some Precambrian granites and gneisses. Mineral. Mag. 1974, 39, 587-594. [CrossRef]

8. Pin, C.; Lancelot, J. U-Pb dating of an Early Paleozoic bimodal magmatism in the French Massif Central and of its further metamorphic evolution. Contrib. Mineral. Petrol. 1982, 79, 1-12. [CrossRef]

9. Charoy, B.; Raimbault, L. Zr, Th, and REE-rich biotite differentiates in the A-type granite pluton of Suzhou (Eastern China): The key role of fluorine. J. Petrol. 1994, 35, 919-962. [CrossRef]

10. Kusiak, M.A.; Dunkley, D.J.; Słaby, E.; Martin, H.; Budzyń, B. Sensitive high-resolution ion microprobe analysis of zircon reequilibrated by late magmatic fluids in a hybridized pluton. Geology 2009, 37, 1063-1066. [CrossRef]

11. Kovaleva, E.; Harlov, D.; Klötzli, U. Complicated secondary textures in zircon record evolution of the host granitic rocks: Studies from Western Tauern Window and Ötztal-Stubai Crystalline Complex (Eastern Alps, Western Austria). Lithos 2017, 284-285, 381-400. [CrossRef] 
12. Peucat, J.J.; Bernard-Griffiths, J.; Gil Ibarguchi, J.I.; Dallmeyer, R.D.; Menot, R.P.; Cornichet, J.; Iglesias Ponce De Leon, M. Geochemical and geochronological cross section of the deep Variscan crust: The Cabo Ortegal high-pressure nappe (northwestern Spain). Tectonophysics 1990, 177, 263-292. [CrossRef]

13. Rimša, A.; Whitehouse, M.J.; Johansson, L.; Piazolo, S. Brittle fracturing and fracture healing of zircon: An integrated cathodoluminescence, EBSD, U-Th-Pb, and REE study. Am. Mineral. 2007, 92, 1213-1224. [CrossRef]

14. Kovaleva, E.; Klötzli, U.; Habler, G.; Libowitzky, E. Finite lattice distortion patterns in plastically deformed zircon grains. Solid Earth 2014, 5, 1099-1122. [CrossRef]

15. Bohor, B.F.; Betterton, W.J. Shocked zircons in the Onaping formation: Further proof of impact origin. In Meteorite Impacts and Planetary Evolution; LPI Contribution: Houston, TX, USA, 1992; Volume 790, pp. 9-10.

16. Bohor, B.F.; Betterton, W.J.; Krogh, T.E. Impact-shocked zircons: Discovery of shock-induced textures reflecting increasing degrees of shock metamorphism. Earth Planet. Sci. Lett. 1993, 119, 419-424. [CrossRef]

17. Kamo, S.L.; Krogh, T.E. Chicxulub crater source for shocked zircon crystals from the Cretaceous-Tertiary boundary layer, Saskatchewan: Evidence from new U-Pb data. Geology 1995, 23, 281-284. [CrossRef]

18. Wittmann, A.; Kenkmann, T.; Schmitt, R.T.; Stöffler, D. Shock-metamorphosed zircon in terrestrial impact craters. Meteorit. Planet. Sci. 2006, 41, 433-454. [CrossRef]

19. Kamo, S.L.; Lana, C.; Morgan, J.V. U-Pb ages of shocked zircon grains link distal K-Pg boundary sites in Spain and Italy with the Chicxulub impact. Earth. Planet Sci. Lett. 2011, 310, 401-408. [CrossRef]

20. Krogh, T.E.; Kamo, S.L.; Bohor, B.F. Fingerprinting the K/T impact site and determining the time of impact by $\mathrm{U}-\mathrm{Pb}$ dating of single shocked zircons from distal ejecta. Earth Planet. Sci. Lett. 1993, 119, 425-429. [CrossRef]

21. Kamo, S.L.; Reimold, W.U.; Krogh, T.E.; Colliston, W.P. A 2.023 Ga age for the Vredefort impact event and a first report of shock metamorphosed zircons in pseudotachylitic breccias and Granophyre. Earth Planet. Sci. Lett. 1996, 144, 369-387. [CrossRef]

22. Moser, D.E.; Cupelli, C.L.; Barker, I.R.; Flowers, R.M.; Bowman, J.R.; Wooden, J.; Hart, J.R. New zircon shock phenomena and their use for dating and reconstruction of large impact structures revealed by electron nanobeam (EBSD, CL, EDS) and isotopic U-Pb and (U-Th)/He analysis of the Vredefort dome. Canad. J. Earth Sci. 2011, 48, 117-139. [CrossRef]

23. Cavosie, A.J.; Erickson, T.M.; Timms, N.E.; Reddy, S.M.; Talavera, C.; Montalvo, S.D.; Pincus, M.R.; Gibbon, R.J.; Moser, D. A terrestrial perspective on using ex situ shocked zircons to date lunar impacts. Geology 2015, 43, 999-1002. [CrossRef]

24. Cavosie, A.J.; Timms, N.E.; Erickson, T.M.; Koeberl, C. New clues from Earth's most elusive impact crater: Evidence of reidite in Australasian tektites from Thailand. Geology 2018, 46, 203-206. [CrossRef]

25. Cavosie, A.J.; Timms, N.E.; Ferrière, L.; Rochette, P. FRIGN zircon-The only terrestrial mineral diagnostic of high-pressure and high-temperature shock deformation. Geology 2018, 46, 891-894. [CrossRef]

26. Erickson, T.M.; Pearce, M.A.; Reddy, S.M.; Timms, N.E.; Cavosie, A.J.; Bourdet, J.; Rickard, W.D.A.; Nemchin, A.A. Microstructural constraints on the mechanisms of the transformation to reidite in naturally shocked zircon. Contrib. Mineral. Petrol. 2017, 172, 6. [CrossRef]

27. Kenny, G.G.; Morales, L.F.; Whitehouse, M.J.; Petrus, J.A.; Kamber, B.S. The formation of large neoblasts in shocked zircon and their utility in dating impacts. Geology 2017, 45, 1003-1006. [CrossRef]

28. Kenny, G.G.; Schmieder, M.; Whitehouse, M.J.; Nemchin, A.A.; Morales, L.F.G.; Buchner, E.; Bellucci, J.J.; Snape, J.F. A new U-Pb age for shock-recrystallised zircon from the Lappajärvi impact crater, Finland, and implications for the accurate dating of impact events. Geochim. Cosmochim. Acta 2019, 245, 479-494. [CrossRef]

29. Hauser, N.; Reimold, W.U.; Cavosie, A.J.; Crósta, A.P.; Schwarz, W.H.; Trieloff, M.; Da Silva Maia De Souza, C.; Pereira, L.A.; Rodrigues, E.N.; Brown, M. Linking shock textures revealed by BSE, CL, and EBSD with U-Pb data (LA-ICPMS and SIMS) from zircon from the Araguainha impact structure, Brazil. Meteorit. Planet. Sci. 2019, 54, 2286-2311. [CrossRef]

30. Kovaleva, E.; Zamyatin, D.; Habler, G. Granular zircon from Vredefort granophyre (South Africa) confirms the deep injection model for impact melt in large impact structures. Geology 2019, 47, 691-694. [CrossRef]

31. Timms, N.E.; Reddy, S.M.; Healy, D.; Nemchin, A.A.; Grange, M.L.; Pidgeon, R.T.; Hart, R. Resolution of impact-related microstructures in lunar zircon: A shock-deformation mechanism map. Meteorit. Planet. Sci. 2012, 47, 120-141. [CrossRef] 
32. Grange, M.L.; Pidgeon, R.T.; Nemchin, A.A.; Timms, N.E.; Meyer, C. Interpreting U-Pb data from primary and secondary features in lunar zircon. Geochim. Cosmochim. Acta 2013, 101, 112-132. [CrossRef]

33. Crow, C.A.; McKeegan, K.D.; Moser, D.E. Coordinated U-Pb geochronology, trace element, Ti-in-zircon thermometry and microstructural analysis of Apollo zircons. Geochim. Cosmochim. Acta 2017, 202, 264-284. [CrossRef]

34. Crow, C.A.; Moser, D.E.; McKeegan, K.D. Shock metamorphic history of >4 Ga Apollo 14 and 15 zircons. Meteorit. Planet. Sci. 2019, 54, 181-201. [CrossRef]

35. Zhang, A.-C.; Hsu, W.-B.; Li, X.-H.; Ming, H.-L.; Li, Q.-L.; Liu, Y.; Tang, G.-Q. Impact melting of lunar meteorite Dhofar 458: Evidence from polycrystalline texture and decomposition of zircon. Meteorit. Planet. Sci. 2011, 46, 103-115. [CrossRef]

36. Montalvo, P.E.; Cavosie, A.J.; Kirkland, C.L.; Evans, N.J.; McDonald, B.J.; Talavera, C.; Erickson, T.M.; Lugo-Centeno, C. Detrital shocked zircon provides first radiometric age constraint ( $<1472 \mathrm{Ma})$ for the Santa Fe impact structure, New Mexico, USA. Geol. Soc. Am. Bull. 2019, 131, 845-863. [CrossRef]

37. Brodie, K.H.; Rutter, E.H. Deep crustal extensional faulting in the Ivrea zone of northern Italy. Tectonophysics 1987, 140, 193-212. [CrossRef]

38. Quick, J.E.; Sinigoi, S.; Peressini, G.; Demarchi, G.; Wooden, J.L.; Sbisà, A. Magmatic plumbing of a large Permian caldera exposed to a depth of $25 \mathrm{~km}$. Geology 2009, 37, 603-606. [CrossRef]

39. Rutter, E.H.; Brodie, K.H.; James, T.; Burlini, L. Large-scale folding in the upper part of the Ivrea-Verbano zone, NW Italy. J. Struct. Geol. 2007, 29, 1-17. [CrossRef]

40. Brodie, K.H.; Rutter, E.H.; Evans, P. On the structure of the Ivrea-Verbano Zone (northern Italy) and its implications for present-day lower continental crust geometry. Terra Nova 1992, 4, 34-39. [CrossRef]

41. Brodie, K. Variation in amphibole and plagioclase composition with deformation. Tectonophysics 1981, 78, 385-402. [CrossRef]

42. Brodie, K.; Rutter, E. On the relationship between deformation and metamorphism, with special reference to the behavior of basic rocks. In Metamorphic Reactions: Kinetics, Textures and Deformation; Thompson, A.B., Rubie, D.C., Eds.; Springer: Berlin, Germany, 1985.

43. Techmer, K.S.; Ahrendt, H.; Weber, K. The development of pseudotachylyte in the Ivrea-Verbano Zone of the Italian Alps. Tectonophysics 1992, 204, 307-322. [CrossRef]

44. Pittarello, L.; Pennacchioni, G.; Di Toro, G. Amphibolite-facies pseudotachylytes in Premosello metagabbro and felsic mylonites (Ivrea Zone, Italy). Tectonophysics 2012, 580, 43-57. [CrossRef]

45. Kovaleva, E.; Klötzli, U.; Habler, G.; Wheeler, J. Planar microstructures in zircon from paleo-seismic zones. Am. Mineral. 2015, 100, 1834-1847. [CrossRef]

46. Kovaleva, E.; Klötzli, U.; Habler, G. On the geometric relationship between deformation microstructures in zircon and the kinematic framework of the shear zone. Lithos 2016, 262, 192-212. [CrossRef]

47. Miller, C.; Konzett, J.; Tiepolo, M.; Armstrong, R.A.; Thöni, M. Jadeite-gneiss from the eclogite zone, Tauern Window, Eastern Alps, Austria: Metamorphic, geochemical and zircon record of a sedimentary protholith. Lithos 2007, 93, 68-88. [CrossRef]

48. Selverstone, J.; Morteani, G.; Staude, J.-M. Fluid channeling during ductile shearing: Transformation of granodiorite into aluminous schist in the Tauern Window, Eastern Alps. J. Metamorph. Geol. 1991, 9, 419-431. [CrossRef]

49. Veselá, P.; Söllner, F.; Finger, F.; Gerdes, A. Magmato-sedimentary Carboniferous to Jurassic evolution of the western Tauern window, Eastern Alps (constraints from U-Pb zircon dating and geochemistry). Int. J. Earth Sci. 2011, 100, 993-1027. [CrossRef]

50. Pennacchioni, G.; Mancktelow, N.S. Nucleation and initial growth of a shear zone network within compositionally and structurally heterogeneous granitoids under amphibolite facies conditions. J. Struct. Geol. 2007, 29, 1757-1780. [CrossRef]

51. Selverstone, J. Evidence for east-west crustal extension in the Eastern Alps: Implications for the unroofing history of the Tauern Window. Tectonics 1988, 7, 87-105. [CrossRef]

52. Nasdala, L.; Hanchar, J.M.; Rhede, D.; Kennedy, A.K.; Vaczi, T. Retention of uranium in complexly altered zircon: An example from Bancroft, Ontario. Chem. Geol. 2010, 269, 290-300. [CrossRef]

53. Geisler, T.; Schaltegger, U.; Tomaschek, F. Re-equilibration of zircon in aqueous fluids and melts. Elements 2007, 3, 43-50. [CrossRef] 
54. Soman, A.; Geisler, T.; Tomaschek, F.; Grange, M.; Berndt, J. Alteration of crystalline zircon solid solutions: A case study on zircon from an alkali pegmatite from Zomba-Malosa, Malawi. Contrib. Mineral. Petrol. 2010, 160, 909-930. [CrossRef]

55. Kovaleva, E.; Klötzli, U.; Habler, G.; Huet, B.; Guan, Y.; Rhede, D. The effect of crystal-plastic deformation on isotope and trace element distribution in zircon: Combined BSE, CL, EBSD, FEG-EMPA and NanoSIMS study. Chem. Geol. 2017, 450, 183-198. [CrossRef]

56. Bingen, B.; Austrheim, H.; Whitehouse, M. Ilmenite as a source for zirconium during high-grade metamorphism? Textural evidence from the Caledonides of western Norway and implications for zircon geochronology. J. Petrol. 2001, 42, 355-375. [CrossRef]

57. Piazolo, S.; Austrheim, H.; Whitehouse, M. Brittle-ductile microfabrics in naturally deformed zircon: Deformation mechanisms and consequences for U-Pb dating. Am. Mineral. 2012, 97, 1544-1563. [CrossRef]

58. Gurov, E.P.; Shekhunova, S.B.; Permyakov, V.V. Accessory and opaque minerals in impact melt rocks of the Boltysh structure, Ukraine. Meteorit. Planet. Sci. 2015, 50, 1139-1155. [CrossRef]

59. Schmieder, M.; Tohver, E.; Jourdan, F.; Denyszyn, S.W.; Haines, P.W. Zircons from the Acraman impact melt rock (South Australia): Shock metamorphism, U-Pb and 40Ar/39Ar systematics, and implications for the isotopic dating of impact events. Geochim. Cosmochim. Acta 2015, 161, 71-100. [CrossRef]

60. McGregor, M.; McFarlane, C.R.M.; Spray, J.S. In situ LA-ICP-MS apatite and zircon U-Pb geochronology of the Nicholson Lake impact structure, Canada: Shock and related thermal effects. Earth Planet. Sci. Lett. 2007, 504, 185-197. [CrossRef]

61. Cavosie, A.J.; Timms, N.E.; Erickson, T.M.; Hagerty, J.J.; Hörz, F. Transformations to granular zircon revealed: Twinning, reidite, and $\mathrm{ZrO}_{2}$ in shocked zircon from Meteor Crater (Arizona, USA). Geology 2016, 44, 703-706. [CrossRef]

62. Cox, M.A.; Cavosie, A.J.; Bland, P.A.; Miljković, K.; Wingate, M.T.D. Microstructural dynamics of central uplifts: Reidite offset by zircon twins at the Woodleigh impact structure, Australia. Geology 2018, 46, 983-986. [CrossRef]

63. Cavosie, A.J.; Koeberl, C. Overestimation of threat from $100 \mathrm{Mt}$-class airbursts? High-pressure evidence from zircon in Libyan Desert Glass. Geology 2019, 47, 609-612. [CrossRef]

64. Kusaba, K.; Syono, Y.; Kikuchi, M.; Fukuoka, K. Shock behavior of zircon: Phase transition to scheelite structure and decomposition. Earth Planet. Sci. Lett. 1985, 72, 433-439. [CrossRef]

65. Timms, N.E.; Erickson, T.M.; Pearce, M.A.; Cavosie, A.J.; Schmieder, M.; Tohver, E.; Reddy, S.M.; Zanetti, M.R.; Nemchin, A.A.; Wittmann, A. A pressure-temperature phase diagram for zircon at extreme conditions. Earth-Sci. Rev. 2017, 165, 185-202. [CrossRef]

66. Moser, D.E. Dating the shock wave and thermal imprint of the giant Vredefort impact, South Africa. Geology 1997, 25, 7-10. [CrossRef]

67. Cavosie, A.J.; Quintero, R.R.; Radovan, H.A.; Moser, D.E. A record of ancient cataclysm in modern sand: Shock microstructures in detrital minerals from the Vaal River, Vredefort Dome, South Africa. Geol. Soc. Am. Bull. 2010, 122, 1968-1980. [CrossRef]

68. Poldervaart, A.; Eckelman, F.D. Growth phenomena in zircon of autochthonous granites. Geol. Soc. Am. Bull. 1955, 66, 947-948. [CrossRef]

69. Dietz, R.S. Vredefort ring structure: Meteorite impact scar? J. Geol. 1961, 69, 499-516. [CrossRef]

70. Dence, M.R. Impact melts. J. Geoph. Res. 1971, 76, 5552-5565. [CrossRef]

71. French, B.M. Traces of Catastrophe; LPI Contribution No. 954; Lunar and Planetary Institute: Houston, TX, USA, 1998; 120p. [CrossRef]

72. Osinski, G.R.; Grieve, R.A.F.; Bleacher, J.E.; Neish, C.D.; Pilles, E.A.; Tornabene, L.L. Igneous rocks formed by hypervelocity impact. J. Volcanol. Geotherm. Res. 2018, 353, 25-54. [CrossRef]

73. Gibson, R.L.; Reimold, W.U.; Stevens, G. Thermal-metamorphic signature of an impact event in the Vredefort Dome, South Africa. Geology 1998, 26, 787-790. [CrossRef]

74. Gibson, R.L.; Reimold, W.U.; Ashley, A.J.; Koeberl, C. Metamorphism on the Moon: A terrestrial analogue in the Vredefort dome, South Africa? Geology 2002, 30, 475-478. [CrossRef] 
75. Perchuk, L.L.; Tokarev, D.A.; van Reenen, D.D.; Varlamov, D.A.; Gerya, T.V.; Sazonova, L.V.; Fel'dman, V.I.; Smit, C.A.; Brink, M.C.; Bisschoff, A.A. Dynamic and thermal history of the Vredefort explosion structure in the Kaapvaal craton, South Africa. Petrology 2002, 10, 395-432.

76. Perchuk, L.L.; Sazonova, L.V.; van Reenen, D.D.; Gerya, T.V. Ultramylonites and their significance for the understanding of the history of the Vredefort impact structure, South Africa. Petrology 2003, 11, 114-129.

(C) 2020 by the author. Licensee MDPI, Basel, Switzerland. This article is an open access article distributed under the terms and conditions of the Creative Commons Attribution (CC BY) license (http://creativecommons.org/licenses/by/4.0/). 